\title{
Yaşam Becerileri Eğitim Programının Anasınıfına Devam Eden Çocukların Yaşam Becerilerine ve Sosyal Uyumlarına Etkisinin Incelenmesi'
}

\author{
Yakup YILDIRIM* \\ Zeynep Fulya TEMEL ${ }^{* *}$
}

\begin{abstract}
Öz: Araştırma deseni olarak öntest-sontest kontrol gruplu yarı deneysel desende tasarlanan bu çalışmanın amacı, okul öncesi dönem 5-6 yaş çocuklarına uygulanan yaşam becerileri eğitimi programının çocukların yaşam becerilerine ve sosyal uyumlarına etkililiğini incelemektir. Araştırmanın çalışma grubunu, Ankara il merkezindeki bir vakıf/özel anaokulunda eğitim görmekte olan 5-6 (60-72 aylık) yaş aralığındaki çocuklar oluşturmuştur. Çalışma grubundaki çocuklardan deney ve kontrol grubu olmak üzere iki grup belirlenmiştir. Deney Grubuna (DG) ve Kontrol Grubuna (KG) ön uygulama aşamasında; sırasıyla, Yaşam Becerilerini ölçmek amacıyla, "Okul Öncesi Dönem Yaşam Becerileri Ölçeği”, Sosyal Uyum Becerilerini ölçmek amacıyla, "Sosyal Uyum Beceri Ölçeği" uygulanmıştır. Ön uygulamalardan sonra deney grubuna, araştırmanın amacı doğrultusunda araştırmacılar tarafından okul öncesi dönem (5-6 yaş) çocuklarının gelişim düzeylerine uygun olarak mevcut okul öncesi eğitim programındaki kazanım ve göstergeler de dikkate alınarak hazırlanan, 18 oturum ve 36 bağımsız yaşam becerisi etkinliğinden oluşan "Yaşam Becerileri Eğitim Programı"nın 12 hafta süreyle uygulaması yapılmıştır. Araştırmadan elde edilen bulgulara göre; deney grubunda yer alan çocukların kontrol grubunda yer alan çocuklara oranla öntest ve sontest puanları arasında pozitif yönde anlamlı düzeyde farklılaşma olduğu saptanmıştır.
\end{abstract}

Anahtar Sözcükler: Okul Öncesi Dönem Yaşam Becerileri, Yaşam Becerileri Eğitim Programı, Sosyal Uyum Becerileri

\section{Investigation of the Effect of Life Skills Education Program on Life Skills and Social Adaptations of Children Attending in Kindergarten}

\begin{abstract}
The purpose of this study, which was designed as a research design in a semi-experimental design with the pretest-posttest control group, is to examine the effectiveness of the life skills education program on children's life skills and social adaption that applied to pre-school children of 5-6 years age. The study group of the study consisted of children between 5-6 years old (60-72 months) who are studying in a foundation / private kindergarten in the city center of Ankara. Two groups, namely experimental and control groups, were determined from the children in the study group. At the preliminary application stage to the experimental group (EG) and the control group (CG); "Preschool Life Skills Scale" to measure Life Skills, and "Social Adaptation Skill Scale" to measure Social Adaptation Skills were applied, respectively. After the preliminary applications, "Life Skills Education Program" consisting of 18 sessions and 36 independent life skills activities, prepared by the researcher of the research, by considering the achievements and indicators in the pre-school education program in accordance with the development levels of pre-school children (5-6 years old), has been implemented to the children for 12 weeks. According to the findings obtained from the research, there was a significant difference between the pre-test and post-test scores of the children in the experimental group compared to the children in the control group.
\end{abstract}

Keywords: Preschool Life Skills, Social Adaptation Skills, Life Skills Training Program

1 Bu makale, Prof. Dr. Z. Fulya Temel’in danışmanlığında, Dr. Yakup Yıldırım tarafından 2017 yılında Gazi Üniversitesi Eğitim Bilimleri Enstitüsü’nde hazırlanan “Anasınıfına Devam Eden Çocuklara Uygulanan Yaşam Becerisi Eğitim Programının Çocukların Yaşam Becerilerine ve Sosyal Uyumlarına Etkisi” başlıklı doktora tezinden üretilmiştir.

* Akdeniz Üniversitesi, Eğitim Fakültesi, Okul Öncesi Eğitimi Anabilim Dalı, Antalya, Türkiye, yakupyildirim1986@gmail.com, ORCID: https://orcid.org/0000-0001-5319-5487

** Gazi Üniversitesi, Gazi Eğitim Fakültesi, Okul Öncesi Eğitimi Anabilim Dalı, Antalya, Türkiye, temel.fulya@gmail.com, ORCID: https://orcid.org/0000-0002-5375-3503
}

\section{Atıf için/ To cite:}

Yıldırım, Y. ve Temel, Z. F. (2020). Yaşam becerileri eğitim programının anasınıfına devam eden çocukların yaşam becerilerine ve sosyal uyumlarına etkisinin incelenmesi. Yaşadıkça Eğitim, 34(2), 384-405. 
Çocuklar için kritik bir dönem olan okul öncesi eğitim çocuğun tüm gelişim alanlarında desteklenmesi gereken bir dönemdir (Arı, 2005; Zembat, 2007). Çocuk okul öncesi dönemde sosyalleşmeye adım atmakta ve ileriki yaşamı için temel oluşturacak becerileri bu dönemde edinmektedir. Çocuğun bu yıllarda edindiği beceriler ve deneyimler gelecek yaşamı için temel oluşturmaktadır. Çocuğun desteklenmesi gereken gelişim alanlarının bu yıllardan sonraki dönemlerde desteklenmeye çalışılması çocukta telafisi mümkün olmayan gecikmelere neden olmaktadır (Senemoğlu, 2012; Turaşlı Kuru, 2015; Yavuzer, 2000).

Erken çocukluk döneminde edinilecek yaşam becerileri, "zorlukları aşarak büyüyüp kök salan ve sağlam bir ağaca dönüşen fidan" metaforunda olduğu gibi günümüz çocuklarının hayatlarının her aşamasında "kendi kendine yetebilen (World Health Organization [WHO], 2013)" bireyler olarak yetişmesinde hayati bir önem taşımaktadır. Öyleyse, bu denli öneme sahip beceriler örgüsü olan "Yaşam Becerileri” ni erken çocukluk döneminden başlamak üzere bireyin yaşamına nasıl adapte edebiliriz? Bu soruya verilebilecek tek ve kesin bir yanıt olmamakla birlikte okullarda ve ailede daha bütüncül ve eklektik bir eğitim modeliyle hayatın ve eğitimin her aşamasına harmanlanarak olabileceği söylenebilir. Bu nedenle eğitim kurumlarında verilen eğitimin yaşam becerilerinin ediniminde önemli bir basamak olduğunun farkında olmak önem taşımaktadır (Murthy, 2016).

Okul öncesi dönemde çocuğa verilecek iyi bir eğitimle çocuğun bütüncül gelişimi desteklenerek yaşam becerilerinin de desteklenmesi sağlanabilir. Erken çocukluk yıllarında gelişimin ardışık ve birbirini izleyen aşamalar halinde devam ettiği (Senemoğlu, 2012) göz önünde bulundurulursa, bir becerinin kazanılması diğer becerilerin kazanılmasını da etkilemektedir. Bu nedenle okul öncesi dönem çocuklarının yaşam becerileri desteklenirken (Hanbury, 2008) aynı zamanda bütüncül gelişiminin de eşgüdümlü olarak desteklenmesi gerekmektedir.

Bu açıdan bakıldığında erken çocukluk dönemi içerisine harmanlanmış bir yaşam becerileri eğitimi hiçbir gelişim alanından bağımsız düşünülmemelidir. Çocuğun aktif biçimde katılabileceği yaşam becerileri eğitiminde öğretmen, çocuğa aynı zamanda bütüncül gelişimini destekleyebilecek etkinliklerle zenginleştirilmiş bir eğitim programı sunmalıdır. Eğitim esnasında çocuğun gelişimi takip edilebilmeli, güçlü ve zayıf yönler tespit edilip eğitim farklı durumlara göre planlanabilmelidir.

Yaşam becerilerinin, "Etkili İletişim Becerisi(1)", “Öz Farkındalık Becerisi(2)", "Empati Yeteneği(3)", "Karar Verme Becerisi(4)”, "Yaratıcı Düşünme Becerisi(5)”, "Problem Çözme Becerisi(6)”, "Eleştirel Düşünme Becerisi(7)", "Kişilerarası İlişki Becerisi(8)", "Duygularla Baş Etme Becerisi(9)" ve "Stresle Baş Etme Becerisi(10)" temel bileşenlerinin (Hanbury, 2008; Kord-Noghabi ve Sharifi, 2008; Mangrulkar, Whitman ve Posner, 2001; Yankey ve Biswas, 2011; WHO, 2013) çocuğun diğer gelişim alanlarıyla birlikte desteklenmesi çocuğun yaşamının diğer dönemlerinde ileriki öğrenmelerini güçlendiren bir etki yaratmaktadır; bu durum okul öncesi dönemde verilen eğitimle mümkündür (Mağden ve Şahin, 2002; Poyraz ve Dere, 2003; Ulusoy, 2015). Okul öncesi dönemde çocuğa kazandırılabilecek beceriler örgüsü şeklindeki yaşam becerileri; başta Dünya Sağlık Örgütünün (World Health Organization) raporları olmak üzere birçok kaynakta (Francis, 2007; Hanbury, 2008; Rooth, 2000; Spence, 2003; United Nations Educational, Scientific and Cultural Organization [UNESCO], 2000; WHO, 1999, 2013) Şekil 1'deki gibi tasvir edilmiştir.

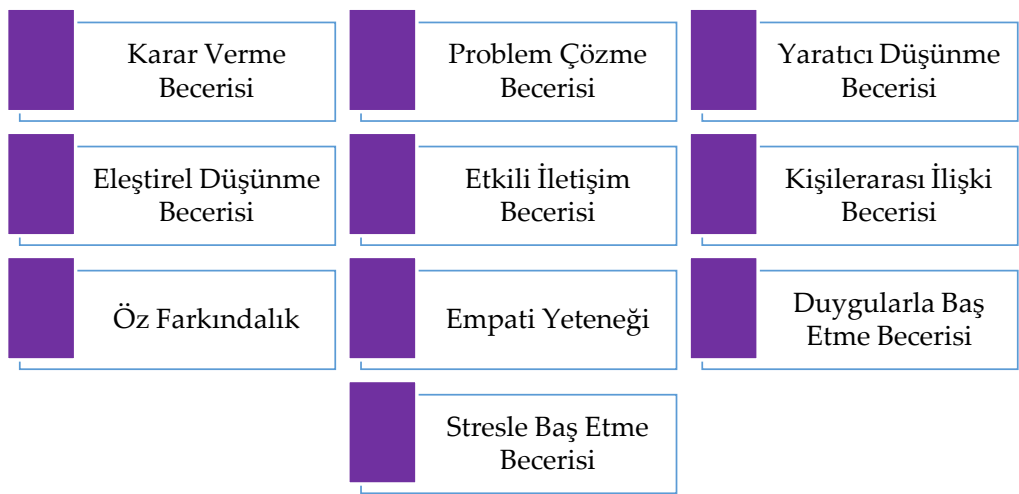

Şekil 1. Yaşam becerilerinin temel bileşenlerini oluşturan beceriler 
Şekil 1'deki beceriler yaşam becerilerinin bütüncül manada içselleştirilebilmesi için temel bileşen olarak değerlendirilen becerilerdir (Rooth, 2000). Yaşam becerilerine ilişkin eğitim programları oluşturulurken bu bileşenlerin bütüncül olarak eğitim programının içine dâhil edilmesine özen gösterilmelidir. Yaşam becerilerinin temel bileşenlerinin oluşturulacak eğitim programındaki ilişkilerine dikkat edilmelidir. Okul öncesi eğitim bireyin eğitim hayatına ilk adım attığı yer olması açısından son derece önem taşımaktadır (Senemoğlu, 2012). Bu nedenle okul öncesi eğitimde verilecek etkili bir yaşam becerileri eğitimi çocuğun bütüncül gelişimine ve dolayısıyla yaşam becerilerinin gelişimine katkı sağlayacaktır. Yaşam becerileri eğitimine okul öncesi eğitimden başlanması çocuklardaki altyapıyı güçlendirecek ve ilerideki yaşamında edineceği üst düzey yaşam becerilerine sağlam bir temel oluşturacaktır (Hanbury, 2008; WHO, 2013).

Erken yaşlarda verilecek her eğitim çocuğun gelişimini olumlu yönde etkiler ve onun başta ilkokul olmak üzere diğer eğitim kademelerine daha hızlı adapte olmasını sağlar. Nitekim birçok araştırma okul öncesi eğitimin çocukların hazır bulunuşluklarına ve okula uyum düzeylerine etki ettiğini göstermektedir (Cinkılıç, 2009; Cinkılıç İnel, Çağdaş ve Temiz, 2012; Erkan, 2011; Esaspehlivan, 2006; Teke, 2010).

Okul öncesi dönemde, yaşam becerilerinin temel bileşenlerine ilişkin eğitim planlanırken bu bileşenlerin kendi içerisinde "bir organizmanın birbirine eklemlenmiş parçaları" (WHO, 2013) olduğu durumu da dikkate alınmalıdır. Yukarıdaki şekilde belirtilen (Şekil 1) yaşam becerilerinin temel bileşenlerinin hangilerinin birbiri ile kompakt bir ilişki içerisinde olduğu Şekil 2' de bağlantılarıyla gösterilmiştir. Temel bileşenlerin bu ilişkisi Dünya Sağlık Örgütü'nün 1999 yılındaki raporunda belirtildiği şekli dikkate alınarak oluşturulmuştur.

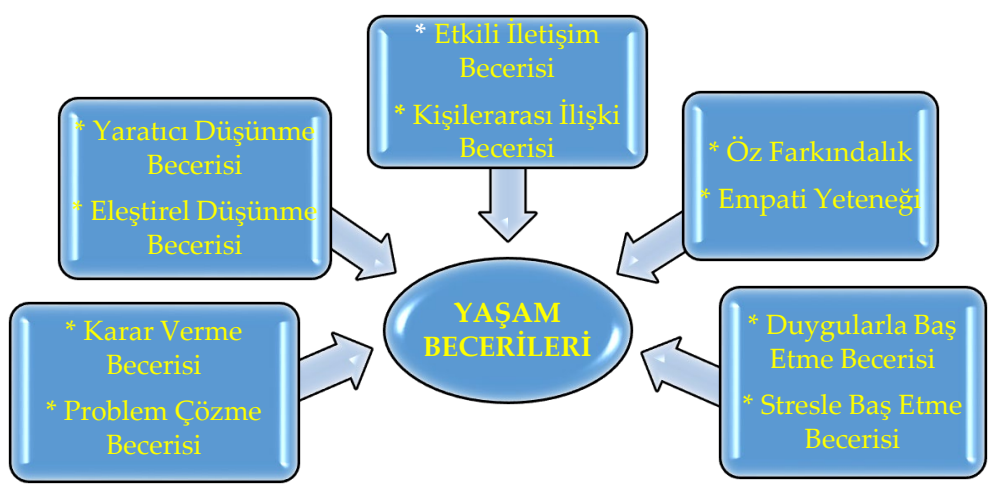

Şekil 2. Yaşam becerilerinin temel bileşen ilişkileri

Şekil 2'de, birbiri ile ilişki içerisinde olan bileşenlerin gruplar halinde birbirine eklemlenerek yaşam becerilerinin temel bileşenlerini oluşturmaları şematize edilmiştir. Bu bileşenler bir bütün olarak ele alındığında, bireyin hayatla ve onun getirdiği zorluklarla başarılı bir şekilde mücadele edebilmesi için gerekli olan kişisel güçlenmenin vazgeçilmez koşulu olarak görülmektedir. Bu durum gelişmekte olan toplumlar için zorunluluktur (De Jong, Ganie, Lazarus ve Prinsloo, 1995). Yaşam becerilerinin geliştirilmesi psikososyal yeterliliği destekler. Yaşam becerileri eğitimi kişinin sosyal yaşamdaki kişisel ve kişiler arası yetkinliğini ve güvenini destekleyerek sorunlarla başa çıkma kaynaklarını geliştirir (Donald, Lazarus ve Lolwana, 1999).

Çocuğun sorunlarla başa çıkma kaynaklarının güçlenmesiyle birlikte ileriki yaşamında edineceği becerilere destek oluşturacak gelişimsel kapasitesi artmaya başlar. Rooth (2000), yaşam becerilerinin temel bileşenlerinin bireyler tarafından içselleştirilmesinin bireydeki kapasite oluşumu sürecini gerçeğe dönüştürdüğünü belirtmektedir. Buradaki kapasite oluşumu ifadesi ile asıl anlatılmak istenen bireyin gelişmesi ve olgunlaşmasıdır. Bu süreç insanların, içinde yaşadığı toplulukta güçlenmelerini ve girişimlerde bulunmalarını sağlamaya yardımcı olan bir süreçtir.

Rooth (2000), çocukta kapasite inşa etme sürecini, yaşam becerileri eğitiminin en önemli ve en temel teması olduğunu vurgulamakla birlikte bu sürecin, yaşam becerilerinin temel bileşenlerinin erken yaşlarda çocuklara kazandırılmasıyla ve onların bu becerileri içselleştirmesiyle mümkün olabileceğini ifade etmektedir. Bu nedenle, okul öncesi dönemde çocuğa sunulacak nitelikli eğitimle desteklenen yaşam becerileri onun tüm 
yönlerden gelişmesini ve kapasitesinin artması sağlar.

Yaşam becerilerinin okul öncesi dönemden başlayarak çocuğa kazandırılmasının öneminin vurgulanması dolayısıyla bu denli öneme sahip bir konu ile ilgili olarak Türkiye alan yazını incelendiğinde; yaşam becerileriyle ilgili yapılan araştırmaların (Erbil ve diğerleri, 2004; Parlakyıldız, 2008; Şentürk Aydın, 2013; Yavuz, 2004) çoğunlukla okul öncesi eğitim seviyesinden daha üst yaş gruplarılla yapıldığı görülmektedir. $\mathrm{Bu}$ nedenle temel amac1; okul öncesi dönem çocuklarına yönelik, yaşam becerilerinin temel bileşenlerini içerisinde barındıran bir "Yaşam Becerileri Eğitim Programı" geliştirmek ve bu programın çocukların yaşam becerileri ile sosyal uyumlarına etkisini incelemek olan bu araştırmada aşağıdaki sorulara yanıt aranmıştır.

A. Yaşam becerileri eğitimine katılan anasınıfı çocuklarının yaşam becerileri ve sosyal uyumları

- Eğitimin etkisine bağlı olarak değişmekte midir?

B. Yaşam becerileri eğitim programı;

- Yaşam becerileri eğitimine katılan çocukların Yaşam Becerisi düzeyleri üzerinde etkili midir?

- Yaşam becerileri eğitimine katılan çocukların Sosyal Uyum Becerisi düzeyleri üzerinde etkili midir?

\section{Yöntem}

\section{Araştırmanın Modeli}

$\mathrm{Bu}$ araştırmada; okul öncesi eğitim kurumuna devam eden 5-6 yaş (60-72 ay) çocuklarına uygulanan "Yaşam Becerileri Eğitim Programı"nın çocukların yaşam becerilerine, sosyal uyumlarına ve iletişim becerilerine etkisinin sinandığı, öntest-sontest kontrol gruplu yarı deneysel desen kullanılmıştır. Howitt (1997)'e göre bu desen karışık bir desen olup, katılımcılar deneysel işlemden önce ve sonra bağımlı değişkenle ilgili olarak ölçülürler (akt. Büyüköztürk, 2007).

Birinci grup olan Deney Grubuna (DG) ve ikinci grup olan Kontrol Grubuna (KG) grupların denkliğinin kontrolü için ön uygulama aşamasında sırasıyla, yaşam becerilerini ölçmek amacıyla, Yıldırım (2017) tarafından geliştirilen "Okul Öncesi Dönem Yaşam Becerileri Ölçeği" ve sosyal uyum becerilerini ölçmek amacıyla, Işık (2007) tarafından geliştirilen "Sosyal Uyum Beceri Ölçeği” uygulanmıştır. Ön uygulamadan sonra deney grubuna 18 oturumdan ve 36 bağımsız yaşam becerisi etkinliğinden oluşan eğitim programının toplamda 12 hafta süreyle uygulaması yapılmıştır. Bu süreçte kontrol grubunda yer alan çocuklar normal müfredat programlarına devam etmişlerdir. 12 haftanın sonunda her iki grupta yer alan öğrencilere ön uygulama aşamasında uygulanan ölçme araçları tekrar uygulanarak son uygulama yapılmıştır.

Son uygulamanın ardından 4 hafta süre geçtikten sonra eğitim programının kalııılığını izlemek amacıyla sadece deney grubuna aynı ölçme araçları tekrar uygulanmıştır. Bu süreci ifade eden desen ön test-son test kontrol gruplu deneysel desen olarak tanımlanmış ve araştırmanın modeli simgesel olarak Tablo 1'de açıklanmıştır.

Tablo I

Ön Test-Son Test Kontrol Gruplu Deneysel Desen Modeli

\begin{tabular}{ccccc}
\hline Grup & Ön Test & Uygulama & Son Test & Kalıc1lık Testi \\
\hline GD & O1 & $X$ & O3 & O5 \\
GK & O2 & - & O4 & - \\
\hline
\end{tabular}

Tablo 1'de "GD" deney grubunu, "GK" kontrol grubunu; "O1" ve "O3", deney grubunun ön ve son test ölçümlerini; "O2" ve "O4", kontrol grubunun ön ve son test ölçümlerini; O5 deney grubuna uygulanan kalıclık testini, " $X$ " ise deney grubundaki çocuklara uygulanan bağımsız değişkeni (deneysel değişkeni) göstermektedir (Büyüköztürk, 2007). Bağımlı değişken olarak yaşam becerileri, sosyal uyum becerileri ve iletişim becerileri belirlenmiştir. O1, O2, O3, O4 ve O5 ölçümlerinde bağımlı değişkenlerle ilişkili ölçme araçları uygulanmıştır. Bağımsız değişken olarak Yaşam Becerileri Eğitim Programı $(\mathrm{X})$ belirlenmiştir. 


\section{Çalışma Grubu}

Araştırmanın çalışma grubunu, Ankara il merkezindeki bir vakıf/özel anaokulunda eğitim görmekte olan 5-6 (60-72 aylık) yaş aralığındaki çocuklar oluşturmuştur. Bu doğrultuda belirlenen okuldan amaçlı örnekleme (benzeşik örnekleme) yöntemi ile deney ve kontrol grubu olmak üzere iki grup belirlenmiştir. Deney ve kontrol gruplarının oluşturulmasında gruplar yansız olarak atanmıştır. Amaçlı örnekleme, araştırmanın amacına uygun olarak belirlenen özellikleri taşıyan bireyleri önceden saptayıp, seçkisiz örneklem olanaksız olduğu durumlarda kullanılır ve burada amaç ilgili özelliklere sahip bireylere ulaşabilmektir (Erkuş, 2013). Deney grubunda $19(\% 52,8)$ kontrol grubunda ise $17(\% 47,2)$ çocuk bulunmaktadır. Çocukların cinsiyetlerine göre gruplardaki dağılımları incelendiğinde, 15'i $(\% 41,7)$ erkek ve 21'i $(\% 58,3)$ kız çocuklardan oluşmaktadır. Deney ve kontrol grubundaki çocukların gelişimsel açıdan bilinen ve tanılanmış özel bir gereksinimi bulunmamaktadır.

\section{Veri Toplama Araçları}

Araştırma verilerini toplamak ve "Okul Öncesi Dönem Yaşam Becerileri Eğitim Programı"nın etkililiğini ölçmek amacıyla, Yıldırım (2017) tarafından geliştirilen “Okul Öncesi Dönem Yaşam Becerileri Ölçeği” ile Işık (2007) tarafından geliştirilen "Sosyal Uyum Beceri Ölçeği" kullanılmıştır.

Yıldırım (2017) tarafından geçerlik-güvenirlik analizleri yapılarak geliştirilen, “Okul Öncesi Dönem Yaşam Becerileri Ölçeği" toplam 44 maddeden ve 7 alt faktörden oluşmaktadır. Okul Öncesi Dönem Yaşam Becerileri Ölçeğinin 7 faktörlü yapısına ait Cronbach Alpha iç tutarlılık katsayıları, faktörlerde yer alan madde sayılarıla birlikte Tablo 2'de verilmiştir.

Tablo II

Okul Öncesi Dönem Yaşam Becerileri Ölçeği'nin Alt Boyutlarnna ve geneline Ait Alpha Güvenirlik Katsayları

\begin{tabular}{lcccccccc}
\hline $\begin{array}{l}\text { Alt } \\
\text { Faktörler }\end{array}$ & $\begin{array}{c}\text { Sosyal } \\
\text { Yaşam }\end{array}$ & Sorumluluk & $\begin{array}{c}\text { Öz- } \\
\text { Farkındalık }\end{array}$ & $\begin{array}{c}\text { Cinsiyet } \\
\text { Farkındalı̆̆ }\end{array}$ & $\begin{array}{c}\text { Karar } \\
\text { Verme }\end{array}$ & $\begin{array}{c}\text { Hayatta } \\
\text { Kalma }\end{array}$ & $\begin{array}{c}\text { Özbakım } \\
\text { Ölçeğin } \\
\text { Geneli }\end{array}$ \\
\hline $\begin{array}{l}\text { Madde } \\
\text { Sayısı }\end{array}$ & 15 & 7 & 6 & 5 & 4 & 4 & 3 & 44 \\
$\mathbf{R}$ & 95 &, 89 &, 86 &, 89 &, 92 &, 83 &, 87 &, 95 \\
\hline
\end{tabular}

Araştırmada kullanılan bir diğer ölçme aracı olan ve Işık (2007) tarafından geliştirilen "Sosyal Uyum Becerileri Ölçeği" ise toplam 26 madde ve 2 alt faktörden oluşmaktadır. 26 maddenin 17'si sosyal uyum alt faktörü ile ilgili, 6'sı sosyal uyumsuzluk alt faktörü ile ilgilidir. Uygulama yapılan gruplarda Sosyal Uyum ve Beceri Ölçeği puanlarının güvenilirliği için Cronbach Alpha değerleri Sosyal Uyum için ,93 Sosyal Uyumsuzluk için ,83 olarak bulunmuştur.

\section{Yaşam Becerileri Eğitim Programının Geliştirilmesi ve Uygulanmasında İzlenen İlkeler}

Araştırma kapsamında öncelikle literatürde yer alan ve okul öncesi çocuklar için uygun olan yaşam becerileri belirlenmiştir. Uygun becerilerin belirlenmesi uzman görüşü alınarak gerçekleştirilmiştir. Belirlenen yaşam becerileri doğrultusunda Okul Öncesi Dönem Yaşam Becerileri Eğitimi Programı oluşturulmuş ve oluşturulan program yine uzman görüşüne sunulmuştur. Uzmanlardan gelen dönütler doğrultusunda gereken düzeltmeler yapılan programa nihai hali verilerek uygulanmıştır.

Programın uygulaması araştırmacılar tarafından 12 hafta süresince yapılmıştır. Haftanın 2 günü toplam 2 oturum olacak şekilde planlanmıştır. Bu oturumlarda ikişer etkinlik yaklaşık 2 saat süre içerisinde uygulanmıştır. Her oturumun başında programın kuramsal temelleri başlı̆̆ının içerisinde yer alan "Sorumluluk Alanı"nındaki görevleri ile ilgili çocuklarla konuşulmuş ve görev değişimleri yapılmıştır. Programda iki adet alan gezisine yer verilmiştir. Bu alan gezilerinin detaylı planları oluşturulmuş ve bu plan çerçevesinde ilgili kurumlarla iletişime geçilerek bilgi verilmiştir. Programın içerisinde detaylı bilgi aktarılacak etkinliklerde uzman konuklardan yardım alınmıştır. Bu kapsamda konuyla ilgili uzman konuk önceden belirlenerek çocukların gelişim düzeyine uygun şekilde aktaracağı bilgiler önceden gözden geçirilmiştir. Uzman konuğun kullanacağ teknik terimler çocukların gelişim düzeyine uygun olacak şekilde konukla birlikte toplantı yapılarak revize edilmiştir. Tüm bu planlamaların sonucunda eğitim programı 18 oturumdan oluşacak şekilde son halini almıştır. Sürecin başında ön testlerin uygulaması yapılmış ve 
Yaşam Becerileri Eğitim Programının Anasınıfına...

uygulamanın sonunda da son testlerin uygulaması yapılmıştır. Son testlerin uygulanmasından 4 hafta sonra kalıcılığı izlemek amacıyla deney grubuna testler tekrar uygulanmıştır.

\section{Veri Toplama Süreci ve Araştırmada İzlenen Etik İlkeler}

Araştırmanın çalışma grubunu oluşturan çocukların anne-babalarına ve öğretmenlerine veri toplama araçlarını (Okul Öncesi Dönem Yaşam Becerileri Ölçeği, Sosyal Uyum Beceri Ölçeği ve Genel Bilgi Formu) nasıl dolduracaklarına dair araştırmacılar tarafından bilgi verilmiştir. Öncelikle ön uygulama yapılıp veriler toplandıktan sonra çocuklara "Yaşam Becerileri Eğitim Programı" uygulanmıştır. Programın uygulanmasından sonra son test verileri toplanmıştır. Son uygulamanın yapılmasını takip eden dördüncü hafta sonunda deney grubuna kalıcılığı izleme testi uygulanmıştır. Araştırmada programın uygulanmasında ve veri toplama sürecinde deney ve kontrol grubunda yer alan çocukların kişisel bilgileri gizli tutulmuştur.

\section{Verilerin Analizi ve Uygulama Güvenirliği}

Uygulama güvenirliği kapsamında eğitim programının bütün uygulama süreci video kayıt altına alınmıştır. Bu video kayıtları iki alan uzmanı tarafından kontrol listesi eşliğinde incelenerek değerlendirilmiştir. Uzmanların kontrol listelerindeki değerlendirmeleri karşılaştırılarak büyük oranda tutarlık gösterdiği tespit edilmiştir. Normallik varsayımının bir ölçüsü olarak çarpıklık ve basıklık katsayılarının - 1 ile +1 aralığında olmasının kabul edilebileceği ifade edilmektedir (Leech, Morgan, Gloeckner ve Barrett, 2004). Test varyanslarının homojenliği yani Levene homojenlik testine ait dağılım incelendiğinde Levene İstatistiği p $\gg, 05$ 'e göre puan dağılımına ait test varyanslarının homojen dağıldı̆̆ı yani homojenlik varsayımının sağlandığı sonucuna ulaşılmıştır. Ölçeklere ait elde edilen puan dağılımının sürekli veri olduğu ve eşit aralıklı ölçek düzeyinde olduğu görülmektedir. İki örneklemin (grup) birbirinden bağımsız olması, bağımlı değişkenlerin aralık veya oran ölçek düzeyinde ölçülmüş olması, normallik ve homojenlik varsayımlarının sağlanması parametrik test varsayımlarını karşılamaktadır. Grup sayıları kimilerine göre 30 ve kimilerine göre 15'in altına düştüğünde puanların normal dağıldığını varsaymak güçtür. Bununla birlikte küçük gruplu deneysel çalışmalar yapan araştırmacıların, topladıkları verilerin dağılımlarının uygun olması durumunda parametrik istatistikleri kullandıkları görülmektedir (Köklü, Büyüköztürk ve Bökeoğlu, 2007). Bu bağlamda toplanan verilerin dağılımlarının parametrik test varsayımlarını sağladığı tespit edilmiş ve deneykontrol grubundaki ölçümlerin karşılaştırılmasında bağımsız örneklem t-testi ve eşleştirilmiş örneklem t-testi kullanılmıştır. Parametrik testlerden bu testlerin seçilmesinin sebeplerinden birisi, çocuklar için uygulanan ölçme araçlarından elde edilen verilerin çocukların öğretmenlerinden toplanmasıdır. Aynı zamanda deney ve kontrol grubunda bulunan çocukların öntest puanları arasında anlamlı farklılık olmamasından dolayı grupların birbirine denk olduğu görülmektedir. Verilerin analiz edilmesinde, öntest verilerini kontrol altına alma gerekliliği olmadığından dolayı kovaryans analizleri yerine bağımsız örneklem ve eşleştirilmiş örneklem t-testi kullanılması tercih edilmiştir.

\section{Bulgular}

Bu bölümde, araştırmada uygulanan “Okul Öncesi Dönem Yaşam Becerisi Eğitim Programı”nın neticesinde elde edilen bulgulara yer verilmiştir. Bu doğrultuda deney ve kontrol gruplarının Okul Öncesi Dönem Yaşam Becerileri Ölçeği ve Sosyal Uyum Beceri Ölçeği'nin alt boyutları ve genelinden aldıkları puanların eğitimin etkisine bağlı olarak değişip değişmediği ve eğitimin kalıclık etkisi incelenmiştir.

\section{Okul Öncesi Dönem Yaşam Becerileri Ölçeğine İlişkin Bulgular}

Tablo III

Deney ve Kontrol Grubundaki Çocukların Yaşam Becerisi Ölçeğinin Alt Faktörleri ve Geneline İlişkin Ön Test Puanları Arasındaki Farklılığa Ait Bağımsız Örneklemler T-Testi Sonuçları

\begin{tabular}{|c|c|c|c|c|c|c|c|}
\hline Ön Test & Grup & $\mathbf{N}$ & Ortalama & $S$ & $t$ & sd & $\mathrm{p}$ \\
\hline \multirow{2}{*}{ Sosyal Yaşam } & Deney & 19 & 65,63 & 8,71 & \multirow{2}{*}{,- 688} & \multirow{2}{*}{34} & \multirow{2}{*}{ 496 } \\
\hline & Kontrol & 17 & 67,47 & 7,14 & & & \\
\hline \multirow{2}{*}{ Sorumluluk } & Deney & 19 & 26,79 & 3,14 & \multirow{2}{*}{$-1,388$} & \multirow{2}{*}{34} & \multirow{2}{*}{,174 } \\
\hline & Kontrol & 17 & 27,94 & 1,43 & & & \\
\hline
\end{tabular}




\begin{tabular}{|c|c|c|c|c|c|c|c|}
\hline \multirow{2}{*}{ Öz Farkındalık } & Deney & 19 & 27,47 & 2,46 & \multirow{2}{*}{817} & \multirow{2}{*}{34} & \multirow{2}{*}{420} \\
\hline & Kontrol & 17 & 26,65 & 3,57 & & & \\
\hline \multirow{2}{*}{ Cinsiyet Farkındalığ1 } & Deney & 19 & 24,21 & 1,27 & \multirow{2}{*}{1,448} & \multirow{2}{*}{34} & \multirow{2}{*}{157} \\
\hline & Kontrol & 17 & 23,35 & 2,21 & & & \\
\hline \multirow{2}{*}{ Karar verme } & Deney & 19 & 16,89 & 2,02 & \multirow{2}{*}{,- 743} & \multirow{2}{*}{34} & \multirow{2}{*}{463} \\
\hline & Kontrol & 17 & 17,41 & 2,15 & & & \\
\hline \multirow{2}{*}{ Hayatta Kalma } & Deney & 19 & 13,53 & 1,22 & \multirow{2}{*}{$-1,625$} & \multirow{2}{*}{34} & \multirow{2}{*}{,113 } \\
\hline & Kontrol & 17 & 14,47 & 2,18 & & & \\
\hline \multirow{2}{*}{ Öz Bakım } & Deney & 19 & 14,58 & 0,61 & \multirow{2}{*}{1,233} & \multirow{2}{*}{34} & \multirow{2}{*}{,226 } \\
\hline & Kontrol & 17 & 14,24 & 1,03 & & & \\
\hline \multirow[t]{2}{*}{ Yaşam Becerileri } & Deney & 19 & 189,11 & 14,98 & \multirow{2}{*}{,- 472} & \multirow{2}{*}{34} & \multirow{2}{*}{640} \\
\hline & Kontrol & 17 & 191,53 & 15,82 & & & \\
\hline
\end{tabular}

Tablo 3'te deney ve kontrol grubunda bulunan çocukların Okul Öncesi Dönem Yaşam Becerileri Ölçeği'nin alt faktörleri ve geneline ilişkin ön test puanları arasında manidar farklılık olup olmadığına ilişkin bulgular yer almaktadir.

"Sosyal Yaşam" alt faktöründe deney grubunda bulunan çocukların ön test yaşam beceri düzeyleri $(\bar{X}=65,63)$ ile kontrol grubunda bulunan çocukların ön test yaşam beceri düzeyleri $(\bar{X}=67,47)$ arasında $\mathrm{t}_{(34)}=-, 688$, $\mathrm{p}=, 496>, 05$ 'e göre anlamlı farklılık olmadığı görülmektedir. "Sosyal yaşam" alt faktöründe deney ve kontrol grubunda bulunan çocukların yaşam beceri düzeylerinin denk olduğu sonucuna ulaşılmaktadır.

"Sorumluluk" alt faktörüne ilişkin deney ve kontrol grubunda bulunan çocukların ön test yaşam becerisi puanları incelendiğinde; deney grubundaki çocukların yaşam becerisi düzeyleri $(\bar{X}=26,79)$ ile kontrol grubunda bulunan çocukların yaşam becerisi düzeyleri $(\bar{X}=27,94)$ arasında $t_{(34)}=-1,388, p=, 174>, 05$ 'e göre anlamlı farklılık olmadığı saptanmıştır. Deney ve kontrol grubundaki çocukların "Sorumluluk" alt faktöründeki yaşam becerileri düzeylerinin benzer nitelikte olduğu sonucuna ulaşılmaktadır.

“Öz Farkındalık" alt faktörüne ilişkin deney ve kontrol grubundaki çocukların ön test yaşam becerisi puanları incelendiğinde; deney grubundaki çocukların yaşam becerisi düzeyleri $(\bar{X}=27,47)$ ile kontrol grubundaki çocukların yaşam becerisi düzeyleri $(\bar{X}=26,65)$ arasında $t_{(34)}=, 817, p=, 420>, 05^{\prime}$ e göre anlamlı farklılık olmadığı saptanmıştır. "Öz Farkındalık" alt faktörüne ait deney ve kontrol grubundaki çocukların öntest puanları incelendiğinde çocukların bu faktöre yönelik yaşam becerileri düzeylerinin denk olduğu sonucuna ulaşılmaktadır.

Deney ve kontrol grubundaki çocukların "Cinsiyet Farkındalı̆̆ı" alt faktörüne ilişkin yaşam becerileri puanları incelendiğinde; deney grubundaki çocukların yaşam becerileri düzeyleri $(\bar{X}=24,21)$ ile kontrol grubundaki çocukların yaşam becerileri düzeyleri $(\bar{X}=23,35)$ arasında $t_{(34)}=1,448, p=, 157>, 05^{\prime}$ e göre anlamlı farklılık olmadığı saptanmıştır. Deney ve kontrol grubundaki çocukların "Cinsiyet Farkındalığı" alt faktörüne ilişkin puanlarına bakıldığında bu faktöre ait yaşam becerileri düzeylerinin birbirine yakın olduğu sonucuna ulaşılmaktadır.

"Karar Verme" alt faktörüne yönelik olarak deney ve kontrol grubunda yer alan çocukların öntest yaşam becerileri düzeyleri incelendiğinde; deney grubundaki çocukların yaşam becerileri düzeyleri $(\bar{X}=16,89)$ ile kontrol grubundaki çocukların yaşam becerileri düzeyleri $(\bar{X}=17,41)$ arasında $\mathrm{t}_{(34)}=-, 743, \mathrm{p}=, 463>, 05^{\prime}$ e göre anlamlı farklılık olmadığı sonucuna ulaşılmıştır. "Karar Verme" alt faktörüne ilişkin deney ve kontrol grubundaki çocukların puanları incelendiğinde bu faktöre yönelik yaşam becerileri seviyelerinin birbirine yakın olduğu sonucuna ulaşılmaktadır.

"Hayatta Kalma" alt faktörüne ilişkin deney ve kontrol grubundaki çocukların öntest yaşam becerileri düzeyleri incelendiğinde; deney grubunda yer alan çocukların yaşam becerileri düzeyleri $(\bar{X}=13,53)$ ile kontrol grubundaki çocukların yaşam becerileri düzeyleri $(\bar{X}=14,47)$ arasında $t(34)=-1,625, \mathrm{p}=, 113>, 05^{\prime}$ e göre anlamlı farklılık olmadığı sonucuna ulaşılmıştır. Deney ve kontrol grubundaki çocuklardan "Hayatta Kalma" alt 
faktörüne ilişkin olarak elde edilen ön test yaşam becerileri puanları incelendiğinde seviyelerinin birbirine yakın olduğu sonucuna ulaşılmaktadır.

“Öz Bakım" alt faktörüne ilişkin deney ve kontrol grubundaki çocukların ön test yaşam becerileri düzeyleri incelendiğinde; deney grubunda yer alan çocukların yaşam becerileri düzeyleri $(\bar{X}=14,58)$ ile kontrol grubunda yer alan çocukların yaşam becerileri düzeyleri $(\bar{X}=14,24)$ arasında $t_{(34)}=1,233, p=, 226>, 05^{\prime}$ e göre anlamlı farklılık olmadığı saptanmıştır. "Öz Bakım” alt faktörüne yönelik olarak deney ve kontrol grubundan elde edilen yaşam becerileri puanları incelendiğinde her iki grubunda düzeylerinin birbirine denk olduğu sonucuna ulaşılmaktadır.

\section{Okul Öncesi Dönem Yaşam Becerileri Ölçeğinin Geneline İlişkin Ön Test Bulguları}

Tablo 3'teki deney ve kontrol grubunda bulunan çocukların Okul Öncesi Dönem Yaşam Becerisi Ölçeği'nin geneline ilişkin ön test puanları incelendiğinde; deney grubunda yer alan çocukların Okul Öncesi Dönem Yaşam Becerileri Ölçeği'nin geneline ilişkin yaşam becerileri düzeyi $(\bar{X}=189,11)$ ile kontrol grubunda yer alan çocukların yaşam becerileri düzeyi $(\bar{X}=191,53)$ arasında $t_{(34)}=-, 472 p=, 640>, 05$ 'e göre anlamlı farklılık olmadığı saptanmıştır. Bu bilgiler doğrultusunda deney ve kontrol grubunda yer alan çocukların “Okul Öncesi Dönem Yaşam Becerileri Ölçeği"nin geneline ilişkin öntest puanlarından hem deney hem kontrol grubundaki çocukların yaşam becerileri düzeylerinin birbirine denk olduğuna yönelik sonuca ulaşılmaktadır. Bu durum deney grubuna uygulama yapılmadan önce her iki grubunda yaşam becerileri düzeylerinin istatistiksel anlamda birbirinden ayrışmadığını göstermektedir.

Tablo 4'te deney ve kontrol grubunda bulunan çocukların yaşam becerisi ölçeğinin alt faktörleri ve geneline ilişkin son test puanları arasında manidar farklılık olup olmadığına ilişkin bulgular verilmiştir.

\section{Tablo IV}

Deney ve Kontrol Grubundaki Çocukların Yaşam Becerisi Ölçeğinin Alt Faktörleri ve Geneline İlişkin Son Test Puanları Arasındaki Farklllı̆̆a Ait Bağımsız Örneklemler T-Testi Sonuçları

\begin{tabular}{|c|c|c|c|c|c|c|c|}
\hline Son Test & Grup & $\mathbf{N}$ & Ortalama & $\mathrm{S}$ & $t$ & sd & $\mathbf{p}$ \\
\hline \multirow{2}{*}{ Sosyal Yaşam } & Deney & 19 & 71,68 & 3,27 & \multirow{2}{*}{2,252} & \multirow{2}{*}{34} & \multirow{2}{*}{, $031^{*}$} \\
\hline & Kontrol & 17 & 67,71 & 6,89 & & & \\
\hline \multirow{2}{*}{ Sorumluluk } & Deney & 19 & 33,37 & 1,64 & \multirow{2}{*}{3,768} & \multirow{2}{*}{34} & \multirow{2}{*}{, $001^{*}$} \\
\hline & Kontrol & 17 & 31,53 & 1,23 & & & \\
\hline \multirow{2}{*}{ Öz Farkındalık } & Deney & 19 & 29,21 & 1,87 & \multirow{2}{*}{2,628} & \multirow{2}{*}{34} & \multirow{2}{*}{, $013^{*}$} \\
\hline & Kontrol & 17 & 26,82 & 3,43 & & & \\
\hline \multirow{2}{*}{ Cinsiyet Farkındalığı } & Deney & 19 & 24,95 & 0,23 & \multirow{2}{*}{3,055} & \multirow{2}{*}{34} & \multirow{2}{*}{, $004^{*}$} \\
\hline & Kontrol & 17 & 23,41 & 2,18 & & & \\
\hline \multirow{2}{*}{ Karar verme } & Deney & 19 & 19,21 & 1,18 & \multirow{2}{*}{2,168} & \multirow{2}{*}{34} & \multirow{2}{*}{, $037^{*}$} \\
\hline & Kontrol & 17 & 18,06 & 1,95 & & & \\
\hline \multirow{2}{*}{ Hayatta Kalma } & Deney & 19 & 19,58 & 1,12 & \multirow{2}{*}{8,365} & \multirow{2}{*}{34} & \multirow{2}{*}{, $000^{*}$} \\
\hline & Kontrol & 17 & 16,82 & 0,81 & & & \\
\hline \multirow{2}{*}{ Öz Bakım } & Deney & 19 & 15,00 & 0,00 & \multirow{2}{*}{2,945} & \multirow{2}{*}{34} & \multirow{2}{*}{, $006^{*}$} \\
\hline & Kontrol & 17 & 14,29 & 1,05 & & & \\
\hline \multirow{2}{*}{ Yaşam Becerileri } & Deney & 19 & 213,00 & 6,11 & \multirow{2}{*}{4,239} & \multirow{2}{*}{34} & \multirow{2}{*}{, $000^{*}$} \\
\hline & Kontrol & 17 & 198,65 & 13,29 & & & \\
\hline
\end{tabular}

"Sosyal Yaşam" alt faktöründe deney grubunda bulunan çocukların son test yaşam beceri düzeyleri $(\bar{X}=71,68)$ ile kontrol grubunda bulunan çocukların son test yaşam becerisi düzeyleri $(\bar{X}=67,71)$ arasında $\mathrm{t}_{(34)}=2,25, \mathrm{p}=, 031<, 05$ 'e göre anlamlı farklılık olduğu görülmektedir. Bu anlamlı farklılık, deney grubuna uygulanan eğitim programının Sosyal Yaşam alt boyutuna yönelik yaşam becerisi düzeyleri üzerinde etkili olmasından dolayı, deney grubunda yer alan çocukların "Sosyal Yaşam" alt boyutunda yaşam becerisi düzeylerinin kontrol grubunda bulunan çocukların düzeylerinden daha yüksek olmasından kaynaklanmaktadır.

"Sorumluluk" alt faktörüne yönelik deney ve kontrol grubunda yer alan çocukların son test puanları incelendiğinde; deney grubundaki çocukların yaşam becerisi düzeyleri $(\bar{X}=33,37)$ ile kontrol grubunda yer alan çocukların yaşam becerisi düzeyleri $(\bar{X}=31,53)$ arasında $\mathrm{t}_{(34)}=3,768, \mathrm{p}=, 001<, 05$ 'e göre anlamlı farklılık 
olduğu görülmektedir. Deney ve kontrol grubundaki çocukların Sorumluluk alt boyutuna yönelik olarak sontest puanları arasındaki anlamlı farklılaşma deney grubuna verilen eğitimin "Sorumluluk" alt boyutuna yönelik yaşam becerisi düzeyleri üzerinde etkili olmasından dolayı, deney grubundaki çocukların kontrol grubundaki çocuklara göre Sorumluluk alt boyutunda yaşam becerisi düzeylerinin daha yüksek olmasından kaynaklanmaktadır.

Deney ve kontrol grubunda yer alan çocukların “Öz Farkındalık" alt faktörüne yönelik son test puanları incelendiğinde; deney grubunda bulunan çocukların yaşam becerisi düzeyleri $(\bar{X}=29,21)$ ile kontrol grubunda bulunan çocukların yaşam becerisi düzeyleri $(\bar{X}=26,82)$ arasında $t_{(34)}=2,628, p=013<, 05$ 'e göre anlaml farklılaşma olduğu saptanmıştır. Her iki gruptaki çocuklar arasından deney grubunda yer alan çocukların lehine oluşan bu farklılaşma, deney grubundaki çocuklara uygulanan eğitim programının çocukların "ÖzFarkındalı" alt boyutuna yönelik yaşam becerisi düzeyleri üzerinde etkili olmasından kaynaklanmaktadır.

Okul Öncesi Dönem Yaşam Becerileri Ölçeği'nin “Cinsiyet Farkındalığı” alt faktörüne yönelik olarak deney ve kontrol grubundaki çocukların son test puanları incelendiğinde; deney grubundaki çocukların yaşam becerisi düzeyleri $(\bar{X}=24,95)$ ile kontrol grubundaki çocukların yaşam becerisi düzeyleri $(\bar{X}=23,41)$

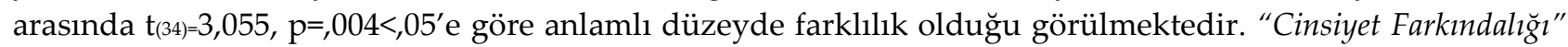
alt faktöründe deney grubu lehine oluşan anlamlı farklılık, deney grubuna verilen eğitimin çocukların yaşam becerileri düzeyleri üzerinde etkili olmasından kaynaklanmaktadır.

"Karar Verme" alt faktörüne yönelik olarak deney ve kontrol grubundaki çocukların son test puanları incelendiğinde; deney grubundaki çocukların yaşam becerisi düzeyleri $(\bar{X}=19,21)$ ile kontrol grubunda yer alan çocukların yaşam becerisi düzeyleri $(\bar{X}=18,06)$ arasında $t_{(34)}=2,168, p=, 037<, 05$ 'e göre anlamlı farklılık olduğu görülmektedir. Deney ve kontrol grubundaki çocukların "Karar Verme" alt boyutuna yönelik olarak sontest puanları arasındaki anlamlı farklılaşma deney grubuna verilen eğitimin "Karar Verme" alt boyutuna yönelik yaşam becerisi düzeyleri üzerinde etkili olmasından dolayı, deney grubundaki çocukların kontrol grubundaki çocuklara göre "Karar Verme" alt boyutunda yaşam becerisi düzeylerinin daha yüksek olmasından kaynaklanmaktadır.

"Hayatta Kalma" alt faktörüne yönelik deney ve kontrol grubunda bulunan çocukların son test puanları incelendiğinde; deney grubundaki çocukların yaşam becerisi düzeyleri $(\bar{X}=19,58)$ ile kontrol grubundaki çocukların yaşam becerisi düzeyleri $(\bar{X}=16,82)$ arasında $t_{(34)}=8,365, p=, 000<, 05$ 'e göre anlamlı düzeyde farklılık olduğu görülmektedir. "Hayatta Kalma" alt faktöründe deney grubu lehine oluşan anlamlı farklılık, deney grubuna verilen eğitimin çocukların yaşam becerileri düzeyleri üzerinde etkili olmasından kaynaklanmaktadır.

Deney ve kontrol grubunda yer alan çocukların “Öz Bakım” alt faktörüne yönelik son test puanları incelendiğinde; deney grubunda bulunan çocukların yaşam becerisi düzeyleri $(\bar{X}=15,00)$ ile kontrol grubunda bulunan çocukların yaşam becerisi düzeyleri $(\bar{X}=14,29)$ arasında $t_{(34)}=2,945, p=, 006<, 05$ 'e göre anlamlı farklılaşma olduğu saptanmıştır. Her iki gruptaki çocuklar arasından deney grubunda yer alan çocukların lehine oluşan bu farklılaşma, deney grubundaki çocuklara uygulanan eğitim programının çocukların "ÖZ Bakım" alt boyutuna yönelik yaşam becerisi düzeyleri üzerinde etkili olmasından kaynaklanmaktadır.

\section{Okul Öncesi Dönem Yaşam Becerileri Ölçeğinin Geneline İlişkin Son Test Bulguları}

Tablo 4'teki deney ve kontrol grubunda bulunan çocukların Okul Öncesi Dönem Yaşam Becerisi Ölçeği'nin geneline ilişkin son test puanları incelendiğinde; deney grubunda yer alan çocukların Okul Öncesi Dönem Yaşam Becerileri Ölçeği'nin geneline ilişkin yaşam becerileri düzeyi $(\bar{X}=213,00)$ ile kontrol grubunda yer alan çocukların yaşam becerileri düzeyi $(\bar{X}=198,65)$ arasında $\mathrm{t}_{(34)}=4,239$, $\mathrm{p}=, 000<, 05^{\prime}$ e göre anlamlı farklılık olduğu sonucuna ulaşılmıştır. Deney ve kontrol grubunda yer alan çocukların Okul Öncesi Dönem Yaşam Becerileri Ölçeği'nin geneline ilişkin sontest puanlarından deney grubundaki çocukların yaşam becerileri düzeylerinin kontrol grubundaki çocukların yaşam becerileri düzeylerine göre farklılaştığı sonucuna ulaşılmaktadır. Ölçeğin geneline ilişkin deney grubu lehine oluşan bu anlamlı farklılık uygulanan eğitim programının etkili olduğunu göstermektedir. 
Tablo 5'te deney ve kontrol grubunda bulunan çocukların yaşam becerisi ölçeğinin alt faktörleri ve geneline ilişkin son test-ön test fark puanları arasında manidar farklılık olup olmadığına ilişkin bulgular verilmiştir.

Tablo V

Deney ve Kontrol Grubundaki Çocukların Yaşam Becerisi Ölçeğinin Alt Faktörleri ve Geneline İlişkin Son Test-Ön Test Fark Puanları Arasındaki Farklılı̆̆a Ait Bă̆ımsız Örneklemler T-Testi Sonuçları

\begin{tabular}{|c|c|c|c|c|c|c|c|}
\hline Sontest-Öntest (Fark Puanı) & Grup & $\mathbf{N}$ & Ortalama & $\mathrm{S}$ & $t$ & sd & $\mathrm{p}$ \\
\hline \multirow{2}{*}{ Sosyal Yaşam } & Deney & 19 & 6,05 & 7,32 & \multirow{2}{*}{3,166} & \multirow{2}{*}{34} & \multirow{2}{*}{, $003^{*}$} \\
\hline & Kontrol & 17 & 0,24 & 2,02 & & & \\
\hline \multirow{2}{*}{ Sorumluluk } & Deney & 19 & 6,58 & 2,97 & \multirow{2}{*}{3,705} & \multirow{2}{*}{34} & \multirow{2}{*}{, $001^{*}$} \\
\hline & Kontrol & 17 & 3,59 & 1,58 & & & \\
\hline \multirow{2}{*}{ Öz Farkındalık } & Deney & 19 & 1,74 & 1,73 & \multirow{2}{*}{2,839} & \multirow{2}{*}{34} & \multirow{2}{*}{, $008^{*}$} \\
\hline & Kontrol & 17 & 0,18 & 1,55 & & & \\
\hline \multirow{2}{*}{ Cinsiyet Farkındalığı } & Deney & 19 & 0,74 & 1,15 & \multirow{2}{*}{2,386} & \multirow{2}{*}{34} & \multirow{2}{*}{, $023^{*}$} \\
\hline & Kontrol & 17 & 0,06 & 0,24 & & & \\
\hline \multirow{2}{*}{ Karar verme } & Deney & 19 & 2,32 & 1,92 & \multirow{2}{*}{3,300} & \multirow{2}{*}{34} & \multirow{2}{*}{, $002^{*}$} \\
\hline & Kontrol & 17 & 0,65 & 0,86 & & & \\
\hline \multirow{2}{*}{ Hayatta Kalma } & Deney & 19 & 2,32 & 1,92 & \multirow{2}{*}{3,300} & \multirow{2}{*}{34} & \multirow{2}{*}{, $002^{*}$} \\
\hline & Kontrol & 17 & 0,65 & 0,86 & & & \\
\hline \multirow{2}{*}{ Öz Bakım } & Deney & 19 & 0,42 & 0,61 & \multirow{2}{*}{2,299} & \multirow{2}{*}{34} & \multirow{2}{*}{, $028^{*}$} \\
\hline & Kontrol & 17 & 0,06 & 0,24 & & & \\
\hline \multirow[b]{2}{*}{ Yaşam Becerileri } & Deney & 19 & 23,89 & 11,27 & \multirow[b]{2}{*}{5,697} & \multirow[b]{2}{*}{34} & \multirow[b]{2}{*}{, $000^{*}$} \\
\hline & Kontrol & 17 & 7,12 & 4,73 & & & \\
\hline
\end{tabular}

“Sosyal Yaşam" alt faktöründe deney grubunda bulunan çocukların son test-ön test fark puanları $(\bar{X}=6,05)$ ile kontrol grubunda bulunan çocukların son test-ön test fark puanları $(\bar{X}=0,24)$ arasında $\mathrm{t}_{(34)}=3,166$, $\mathrm{p}=, 003<, 05$ 'e göre anlamlı farklılık olduğu görülmektedir. Bu anlamlı farklılık, deney grubunda bulunan çocukların eğitim programının uygulanma sürecinde gösterdiği "Sosyal Yaşam" alt faktörüne yönelik yaşam becerilerindeki ön test ile son test arası artış miktarının, kontrol grubunda bulunan çocukların ön test ile son test arası "Sosyal Yaşam" alt faktörüne yönelik yaşam becerilerindeki artış miktarından fazla olmasından kaynaklanmaktadır.

"Sorumluluk" alt faktöründe deney grubunda bulunan çocukların son test-ön test fark puanları $(\bar{X}=6,58)$ ile kontrol grubunda bulunan çocukların son test-ön test fark puanları $(\bar{X}=3,59)$ arasında $t_{(34)}=3,705$, $\mathrm{p}=, 001<, 05$ 'e göre anlamlı farklılık olduğu görülmektedir. Bu anlamlı farklılık, deney ve kontrol grubunda bulunan çocukların ön test ile son testten elde ettikleri "Sorumluluk" alt faktörüne ilişkin olarak yaşam becerilerindeki puanlarında gösterdikleri artışın deney grubundaki çocuklar lehine daha fazla artmasından kaynaklanmaktadır.

“Öz Farkındalık" alt faktörüne ilişkin olarak deney ve kontrol grubunda yer alan çocukların son test-ön test fark puanları incelendiğinde; deney grubunda bulunan çocukların son test-ön test fark puanları $(\bar{X}=1,74)$ ile kontrol grubunda bulunan çocukların son test-ön test fark puanları $(\bar{X}=0,18)$ arasında $\mathrm{t}(34)=2,839$, $\mathrm{p}=, 008<, 05$ 'e göre anlamlı farklılık olduğu görülmektedir. Bu anlamlı farklılı̆̆ın kaynağı, deney grubunda yer alan çocukların kontrol grubundaki çocuklara göre "Öz Farkındalık" alt faktörüne yönelik yaşam becerilerindeki; son test- ön test arasında gösterdikleri artış miktarının daha fazla olmasıdır.

"Cinsiyet Farkındalı̆̆ı" alt faktörüne ilişkin olarak deney ve kontrol grubunda yer alan çocukların son test-ön test fark puanları incelendiğinde; deney grubunda bulunan çocukların son test-ön test fark puanları $(\bar{X}=0,74)$ ile kontrol grubunda bulunan çocukların son test-ön test fark puanları $(\bar{X}=0,06)$ arasında $\mathbf{t}_{(34)}=2,386$, $\mathrm{p}=, 023<, 05$ 'e göre anlamlı farklılık olduğu saptanmıştır. Bu anlamlı farklılık, deney grubunda bulunan çocukların eğitim programının uygulanma sürecinde gösterdiği "Cinsiyet Farkındalı̆̆g" alt faktörüne yönelik yaşam becerilerindeki ön test ile son test arası artış miktarının, kontrol grubunda bulunan çocukların ön test ile son test arası "Cinsiyet Farkındalı̆̆ı" alt faktörüne yönelik yaşam becerilerindeki artış miktarından fazla olmasindan kaynaklanmaktadır. 
"Karar Verme" alt faktörüne ilişkin deney ve kontrol grubunda yer alan çocukların son test-ön test fark puanları incelendiğinde; deney grubunda bulunan çocukların son test-ön test fark puanları $(\bar{X}=2,32)$ ile kontrol grubunda bulunan çocukların son test-ön test fark puanları $(\bar{X}=0,65)$ arasında $t_{(34)}=3,300, p=, 002<, 05^{\prime}$ e göre anlamlı farklılık olduğu görülmektedir. Bu anlamlı farklılık, deney ve kontrol grubunda bulunan çocukların ön test ile son testten elde ettikleri "Karar Verme" alt faktörüne ilişkin olarak yaşam becerilerindeki puanlarında gösterdikleri artışın deney grubundaki çocuklar lehine daha fazla artmasından kaynaklanmaktadır.

“Hayatta Kalma" alt faktöründe deney grubunda yer alan çocukların son test-ön test fark puanları $(\bar{X}=2,32)$ ile kontrol grubunda yer alan çocukların son test-ön test fark puanları $(\bar{X}=0,65)$ arasında $\mathrm{t}_{(34)}=3,300$, $\mathrm{p}=, 002<, 05$ 'e göre anlamlı farklılık olduğu görülmektedir. Bu anlamlı farklılık, deney grubunda bulunan çocukların eğitim programının uygulanma sürecinde gösterdiği "Hayatta Kalma" alt faktörüne yönelik yaşam becerilerindeki ön test ile son test arası artış miktarının, kontrol grubunda bulunan çocukların ön test ile son test arası "Hayatta Kalma" alt faktörüne yönelik yaşam becerilerindeki artış miktarından fazla olmasından kaynaklanmaktadır.

“Öz Bakım” alt faktörüne ilişkin olarak deney ve kontrol grubunda yer alan çocukların son test-ön test fark puanları incelendiğinde; deney grubunda bulunan çocukların son test-ön test fark puanları $(\bar{X}=0,42)$ ile kontrol grubunda bulunan çocukların son test-ön test fark puanları $(\bar{X}=0,06)$ arasında $t_{(34)}=2,299, p=, 028<, 05$ 'e göre anlamlı farklılık olduğu saptanmıştır. Bu anlamlı farklılık, deney grubunda bulunan çocukların eğitim programının uygulanma sürecinde gösterdiği “Öz Bakım” alt faktörüne yönelik yaşam becerilerindeki ön test ile son test arası artış miktarının, kontrol grubunda bulunan çocukların ön test ile son test arası "Öz Bakım" alt faktörüne yönelik yaşam becerilerindeki artış miktarından fazla olmasından kaynaklanmaktadır.

\section{Okul Öncesi Dönem Yaşam Becerileri Ölçeğinin Geneline İlişkin Son Test-Ön Test Fark Puanı Bulguları}

Tablo 5'teki deney ve kontrol grubunda bulunan çocukların Okul Öncesi Dönem Yaşam Becerisi Ölçeği'nin geneline ilişkin son test-ön test fark puanları incelendiğinde; deney grubunda yer alan çocukların Okul Öncesi Dönem Yaşam Becerileri Ölçeği'nin geneline ilişkin son test-ön test fark puanları $(\bar{X}=23,89)$ ile kontrol grubunda yer alan çocukların son test-ön test fark puanları $(\bar{X}=7,12)$ arasında $\mathrm{t}_{(34)}=5,697, \mathrm{p}=, 000<, 05$ 'e göre anlamlı farklılık olduğu sonucuna ulaşılmıştır. Okul Öncesi Dönem Yaşam Becerileri Ölçeği'nin geneline yönelik oluşan bu anlamlı farklılık, deney grubunda yer alan çocukların eğitim programının uygulanması aşamasında ön test ile son test arasındaki süreçte elde ettikleri kazanımların kontrol grubundaki çocuklara göre daha fazla olmasından kaynaklanmaktadır. Bu bağlamda, deney grubundaki çocukların, uygulanan eğitim programının başlangıcından sonuna kadar Yaşam Becerileri düzeylerinde gösterdikleri pozitif değişimin eğitim programının etkili olmasından dolayı oluştuğu söylenebilir.

Tablo 6'da deney grubunda bulunan çocukların yaşam becerisi ölçeğinin alt faktörleri ve geneline ilişkin son test ile izleme testine ait yaşam beceri düzeyleri arasında manidar farklılık olup olmadığına ilişkin bulgular yer almaktadır.

Tablo VI

Deney Grubundaki Çocukların Yaşam Becerisi Ölçeğinin Alt Faktörleri ve Geneline İlişkin Son Test Puanları ile İzleme Testi Puanları Arasındaki Farklilığa Ait Eşleştirilmiş Örneklemler T-Testi Sonuçları

\begin{tabular}{|c|c|c|c|c|c|c|c|}
\hline Alt Faktörler & Testler & $\mathbf{N}$ & Ortalama & $S$ & $t$ & sd & p \\
\hline \multirow{2}{*}{ Sosyal Yaşam } & Son & 19 & 71,68 & 3,27 & \multirow{2}{*}{1,901} & \multirow{2}{*}{18} & \multirow{2}{*}{,073 } \\
\hline & İzleme & 19 & 70,74 & 3,84 & & & \\
\hline \multirow{2}{*}{ Sorumluluk } & Son & 19 & 33,37 & 1,64 & \multirow{2}{*}{1,445} & \multirow{2}{*}{18} & \multirow{2}{*}{ 166 } \\
\hline & İzleme & 19 & 32,89 & 2,26 & & & \\
\hline \multirow{2}{*}{ Öz Farkındalık } & Son & 19 & 29,21 & 1,87 & \multirow{2}{*}{2,001} & \multirow{2}{*}{18} & \multirow{2}{*}{,061 } \\
\hline & İzleme & 19 & 28,00 & 2,31 & & & \\
\hline \multirow{2}{*}{ Cinsiyet Farkındalığ } & Son & 19 & 24,95 & 0,23 & \multirow{2}{*}{,972 } & \multirow{2}{*}{18} & \multirow{2}{*}{,344 } \\
\hline & İzleme & 19 & 24,63 & 1,38 & & & \\
\hline \multirow{2}{*}{ Karar verme } & Son & 19 & 19,21 & 1,18 & \multirow{2}{*}{1,950} & \multirow{2}{*}{18} & \multirow{2}{*}{,067 } \\
\hline & İzleme & 19 & 18,53 & 1,74 & & & \\
\hline \multirow{2}{*}{ Hayatta Kalma } & Son & 19 & 19,58 & 1,12 & - & \multirow{2}{*}{18} & \multirow{2}{*}{ 119 } \\
\hline & İzleme & 19 & 20,00 & 0,00 & 1,637 & & \\
\hline Öz Bakım & Son & 19 & 15,00 & 0,00 & 1,837 & 18 & ,083 \\
\hline
\end{tabular}


Yaşam Becerileri Eğitim Programının Anasınıfına...

\begin{tabular}{|c|c|c|c|c|c|c|c|}
\hline & İzleme & 19 & 14,84 & 0,37 & & & \\
\hline \multirow{2}{*}{ Yaşam Becerileri } & Son & 19 & 213,00 & 6,11 & \multirow{2}{*}{2,041} & \multirow{2}{*}{18} & \multirow{2}{*}{,056 } \\
\hline & İzleme & 19 & 211,68 & 7,10 & & & \\
\hline
\end{tabular}

${ }^{*} \mathrm{p}<, 05$

"Sosyal Yaşam" alt faktöründe deney grubunda bulunan çocukların son teste ait sosyal yaşam becerisi puanı $(\bar{X}=71,68)$ ile izleme testi sosyal yaşam becerisi puanı $(\bar{X}=70,74)$ arasında $\mathrm{t}_{(34)}=1,90, \mathrm{p}=, 073>, 05$ 'e göre anlamlı farklılık olmadı̆̆ı görülmektedir. Süreç bitiminde son test uygulaması yapıldığında elde edilen sosyal yaşam becerisi puanları ile deney grubunda bulunan çocukların belirli bir zaman dilimi geçtikten sonra sosyal yaşam beceri düzeylerini tekrar ölçmek için uygulanan izleme testi puanları arasında bir farklılık olmadığı görülmektedir. Deney grubunda sosyal yaşam bağlamında kalıcılığın gerçekleştiği sonucuna ulaşılmaktadır.

"Sorumluluk" alt faktörüne ilişkin olarak deney grubunda bulunan çocukların son test ve izleme testi puanları incelendiğinde; çocukların son testteki puanı $(\bar{X}=33,37)$ ile izleme testindeki puanı $(\bar{X}=32,89)$ arasında $t_{(34)}=1,445, \quad p=, 166>, 05$ 'e göre anlamlı bir farklılık bulunmadığı saptanmıştır. Eğitim programının tamamlanmasından sonra uygulanan son testlerden izleme testinin yapıldığı zamana kadar geçen sürede deney grubundaki çocuklarda "Sorumluluk" alt faktörüne ilişkin olarak edinilen becerilerde kalıcılığın oluştuğu ifade edilebilir.

Deney grubunun "Öz Farkındalık" alt faktörüne ilişkin son test ve izleme testi puanları incelendiğinde; çocukların son testteki puanı $(\bar{X}=29,21)$ ile izleme testindeki puanı $(\bar{X}=28,00)$ arasında $\mathrm{t}_{(34)}=2,001, \mathrm{p}=, 061>, 05$ 'e göre anlamlı bir farklılık bulunmadığı görülmektedir. Bu anlamlı farklılı̆̆ın oluşmamış olması, iki test arasındaki süreçte çocukların "Öz Farkındalık" alt faktörüne ilişkin kazandıkları becerilerde kalıcı etkinin varlığıyla ilişkilendirilebilir. Bu açıdan deney grubunda “Öz Farkındalık" ile ilgili becerilerde kalıcılığın gerçekleştiği sonucuna ulaşılmaktadır.

"Cinsiyet Farkındalı̆̆ı" alt faktörüne ait deney grubundaki çocukların son test ve izleme testi puanları incelendiğinde; son teste ilişkin puanları $(\bar{X}=24,95)$ ile izleme testine ilişkin puanları $(\bar{X}=24,63)$ arasında $t_{(34)}=$ ,972, p=,344>,05'e göre anlamlı bir farklılık saptanmadığı görülmektedir. "Cinsiyet Farkındalığı" alt faktörüne ilişkin olarak deney grubundaki çocukların son test ve izleme testi puanları arasında anlamlı bir farklılaşmanın olmaması çocukların cinsiyet farkındalığına ait edindiği becerilerin kalıcı bir etki içerdiği söylenebilir.

Deney grubundaki çocukların "Karar Verme" alt faktörüne yönelik olarak son test ve izleme testinden aldıkları puanlar incelendiğinde; son test puanları $(\bar{X}=19,21)$ ile izleme testi puanları $(\bar{X}=18,53)$ arasında $\mathrm{t}(34)=$ $1,950, \mathrm{p}=, 067>, 05$ 'e göre anlamlı bir farklılık bulunamamıştır. Dolayısıyla deney grubundaki çocukların son test ve izleme testinden "Karar Verme" alt faktörüne ilişkin kazandı̆̆ı becerilerde iki test arasında geçen zamanda kalıcı bir etki gösterdiği ifade edilebilir.

"Hayatta Kalma" alt faktörüne ilişkin aldıkları puanlar incelendiğinde deney grubundaki çocukların son test puanları $(\bar{X}=19,58)$ ile izleme testi puanları $(\bar{X}=20,00)$ arasında $t_{(34)}=-1,637, p=, 119>, 05$ 'e göre anlamlı bir fark görülmemektedir. Bu bilgiler doğrultusunda "Hayatta Kalma" alt faktörüne ilişkin olarak deney grubundaki çocukların becerilerindeki süreklilik ve kalıcı etkinin devam ettiği söylenebilir.

“Öz Bakım" alt faktörüne yönelik deney grubundaki çocukların son test ve izleme testinden aldıkları puanlar incelendiğinde; son test puanı $(\bar{X}=15,00)$ ile izleme testi puanı $(\bar{X}=14,84)$ arasında $t(34)=1,837$, $\mathrm{p}=, 083>, 05$ 'e göre anlamlı bir farklılık saptanmamıştır. İki test arasında geçen süreçte “Öz Bakım” alt faktörüne ilişkin kazanılan becerilerde anlamlı bir farklılaşmanın olmaması deney grubundaki çocuklarda bu becerilerin kalıcı bir etki göstermesinden kaynaklanmaktadır.

\section{Okul Öncesi Dönem Yaşam Becerileri Ölçeğinin Geneline İlişkin Son Test ve İzleme Testi Bulguları}

Tablo 6'daki deney grubunda bulunan çocukların “Okul Öncesi Dönem Yaşam Becerisi Ölçeği”nin geneline ilişkin son test ve izleme testi puanları incelendiğinde; son test puanları $(\bar{X}=213,00)$ ile izleme testi puanları $(\bar{X}=211,68)$ arasında $\mathrm{t}_{(34)}=2,041, \mathrm{p}=, 056>, 05$ 'e göre anlamlı farklılık oluşmadı ̆̆ sonucuna ulaşılmıştır. 
Deney grubundaki çocukların “Okul Öncesi Dönem Yaşam Becerileri Ölçeğinin” geneline ilişkin olarak kazandığı beceriler açısından son test ve izleme testinde anlamlı bir farklılığın oluşmamış olması çocukların bu becerileri sergilemede sürekli ve kalıcı bir etki göstermelerinden kaynaklanmaktadır. Bu bilgiler ışığında deney grubundaki çocukların ölçeğin geneline ilişkin kazandıkları becerilerinde kalıcılığın oluştuğu söylenebilir.

\section{Sosyal Uyum Beceri Ölçeğine İlişkin Bulgular}

Tablo 7'de Sosyal Uyum Beceri Ölçeğinin alt faktörlerine ilişkin deney ve kontrol grubunda bulunan çocukların ön test uygulamaları arasında anlamlı farklılık olup olmadığına ilişkin bulgular yer almaktadır.

Tablo VII

Deney ve Kontrol Grubundaki Çocukların Sosyal Uyum Beceri Ölçeğinin Alt Faktörlerine İlişkin Ön Test Puanları Arasındaki Farklılı̆̆a Ait Bă̆ımsız Örneklemler T-Testi Sonuçları

\begin{tabular}{llllllll}
\hline Ön Test & Grup & N & Ortalama & S & t & sd & p \\
\hline \multirow{2}{*}{ Sosyal Uyum } & Deney & 19 & 27,11 & 3,18 & \multirow{2}{*}{, 329} & \multirow{2}{*}{34} & \multirow{2}{*}{, 744} \\
& Kontrol & 17 & 26,82 & 1,63 & & & \multirow{2}{*}{34} \\
\multirow{2}{*}{ Sosyal Uyumsuzluk } & Deney & 19 & 11,16 & 1,57 & \multirow{2}{*}{, 998} & 34 \\
& Kontrol & 17 & 11,71 & 1,72 & & \\
\hline
\end{tabular}
${ }^{{ }^{*} \mathrm{p}<, 05}$

"Sosyal Uyum" alt faktöründe deney grubunda bulunan çocukların ön test sosyal uyum beceri düzeyleri $(\bar{X}=27,11)$ ile kontrol grubunda bulunan çocukların ön test sosyal uyum beceri düzeyleri $(\bar{X}=26,82)$ arasında $\mathrm{t}_{(34)}=, 329, \mathrm{p}=, 744>, 05$ 'e göre anlamlı farklılık olmadığı görülmektedir. Deney ve kontrol grubunda bulunan çocukların ön test puanları incelendiğinde "Sosyal Uyum" alt faktöründe beceri düzeylerinin anlamlı düzeyde farklılaşmadığı ve iki grubunda birbirine yakın değerler gösterdiği sonucuna ulaşılmaktadır.

Deney ve kontrol grubundaki çocukların "Sosyal Uyumsuzluk" alt faktörüne ilişkin ön test puanları incelendiğinde; deney grubundaki çocukların sosyal uyumsuzluk beceri düzeyleri $(\bar{X}=11,16)$ ile kontrol grubunda bulunan çocukların sosyal uyumsuzluk beceri düzeyleri $(\bar{X}=11,71)$ arasında $\mathrm{t}_{(34)}=-, 998, \mathrm{p}=, 326>, 05^{\prime} \mathrm{e}$ göre anlamlı farklılık olmadığı saptanmıştır. Deney ve kontrol grubundaki çocukların "Sosyal Uyumsuzluk" alt faktöründeki uyumsuzluk becerisi düzeylerinin benzer nitelikte olduğu sonucuna ulaşılmaktadır.

Tablo 8'de Sosyal Uyum Beceri Ölçeği'nin alt faktörlerine ilişkin deney ve kontrol grubunda bulunan çocukların son test uygulamaları arasında anlamlı farklılık olup olmadığına ilişkin bulgular yer almaktadır.

\section{Tablo VIII}

Deney ve Kontrol Grubundaki Çocukların Sosyal Uyum Beceri Ölçeğinin Alt Faktörlerine İlişkin Son Test Puanları Arasındaki Farklılı̆̆a Ait Bağımsız Örneklemler T-Testi Sonuçları

\begin{tabular}{llllllll}
\hline Son Test & Grup & $\mathbf{N}$ & Ortalama & S & $\mathbf{t}$ & sd & $\mathbf{p}$ \\
\hline \multirow{2}{*}{ Sosyal Uyum } & Deney & 19 & 33,00 & 1,60 & \multirow{2}{*}{12,797} & \multirow{2}{*}{34} & \multirow{2}{*}{$000^{*}$} \\
& Kontrol & 17 & 27,76 & 0,56 & & \\
\multirow{2}{*}{ Sosyal Uyumsuzluk } & Deney & 19 & 12,16 & 1,38 & $-5,037$ & 34 & \multirow{2}{*}{, $000^{*}$} \\
\hline
\end{tabular}
${ }^{* \mathrm{p}<, 05}$

Deney ve kontrol grubunda yer alan çocukların "Sosyal Uyum" alt faktörüne yönelik son test puanları incelendiğinde; deney grubundaki çocukların son test sosyal uyum becerisi düzeyleri $(\bar{X}=33,00)$ ile kontrol grubundaki çocukların son test sosyal uyum becerisi düzeyleri $(\bar{X}=27,76)$ arasında $\mathrm{t}_{(34)}=12,797, \mathrm{p}=, 000<, 05^{\prime} \mathrm{e}$ göre anlamlı farklılık olduğu görülmektedir. Bu anlamlı farklılık, deney grubundaki çocuklara uygulanan eğitim programının "Sosyal Uyum" alt faktörüne yönelik beceri düzeyleri üzerinde etkili olmasından dolayı; deney grubundaki çocukların "Sosyal Uyum" alt faktöründeki beceri düzeylerinin kontrol grubunda bulunan çocukların beceri düzeylerinden daha yüksek olmasından kaynaklanmaktadır. Uygulanan eğitim programının, deney grubundaki çocukların "Sosyal Uyum" alt faktörüne yönelik becerilerine anlamlı düzeyde etki ettiği sonucuna ulaşılmaktadır.

"Sosyal Uyumsuzluk" alt faktörüne yönelik olarak deney ve kontrol grubundaki çocukların son test puanları incelendiğinde; deney grubundaki çocukların son test sosyal uyumsuzluk düzeyleri $(\bar{X}=12,16)$ ile 
kontrol grubundaki çocukların son test sosyal uyumsuzluk düzeyleri $(\bar{X}=14,18)$ arasında $\mathrm{t}_{(34)}=-5,037$, $\mathrm{p}=, 000<, 05$ 'e göre anlamlı farklılık olduğu görülmektedir.

$\mathrm{Bu}$ anlamlı farklılaşma deney grubunun sosyal uyumsuzluk düzeylerinde kontrol grubuna göre negatif yönde bir değişim olmasından kaynaklanmaktadır. Bu sonuca göre deney grubundaki çocuklara uygulanan Yaşam Becerisi Eğitim Programının çocukların Sosyal Uyumsuzluk davranışı sergileme düzeylerine negatif yönde bir etki ettiği sonucuna ulaşılmaktadır. Uygulanan eğitim programının deney grubunda sergilenen sosyal uyumsuzluk davranışlarının azalmasında etkili olduğu söylenebilir.

Tablo 9'da Sosyal uyum beceri ölçeğinin alt faktörlerine ilişkin deney ve kontrol grubunda bulunan çocukların son test-ön test fark puanları arasında anlamlı farklılık olup olmadığına ilişkin bulgular yer almaktadır.

Tablo IX

Deney ve Kontrol Grubundaki Çocukların Sosyal Uyum Beceri Ölçeğinin Alt Faktörlerine İlişkin Son Test-Ön Test Fark Puanları Arasındaki Farklılı̆̆a Ait Bă̆ımsız Örneklemler T-Testi Sonuçları

\begin{tabular}{|c|c|c|c|c|c|c|c|}
\hline Son Test-Ön Test (Fark Puanı) & Grup & $\mathbf{N}$ & Ortalama & $S$ & $t$ & sd & $\mathbf{p}$ \\
\hline \multirow{2}{*}{ Sosyal Uyum } & Deney & 19 & 5,89 & 2,58 & \multirow{2}{*}{6,911} & \multirow{2}{*}{34} & \multirow{2}{*}{, $000^{*}$} \\
\hline & Kontrol & 17 & 0,94 & 1,52 & & & \\
\hline \multirow{2}{*}{ Sosyal Uyumsuzluk } & Deney & 19 & 1,00 & 1,73 & \multirow{2}{*}{$-2,424$} & \multirow{2}{*}{34} & \multirow{2}{*}{, $021^{*}$} \\
\hline & Kontrol & 17 & 2,47 & 1,91 & & & \\
\hline
\end{tabular}
${ }^{* \mathrm{p}<}<05$

"Sosyal Uyum" alt faktöründe deney grubunda bulunan çocukların son test-ön test fark puanları $(\bar{X}=5,89)$ ile kontrol grubunda bulunan çocukların son test-ön test fark puanları $(\bar{X}=0,94)$ arasında $\mathrm{t}_{(34)}=6,911$, $\mathrm{p}=, 000<, 05$ 'e göre anlamlı farklılık olduğu görülmektedir. Bu anlamlı farklılık, deney grubunda bulunan çocukların eğitim programının uygulanma sürecinde gösterdiği "Sosyal Uyum" alt faktörüne yönelik becerilerindeki ön test ile son test arası artış miktarının, kontrol grubunda bulunan çocukların ön test ile son test arası "Sosyal Uyum" alt faktörüne yönelik becerilerindeki artış miktarından fazla olmasından kaynaklanmaktadır. Yaşam Becerileri Eğitim programının uygulanması sürecinde deney grubundaki çocukların kontrol grubundaki çocuklara göre verilen eğitimden kaynaklı olarak "Sosyal Uyum" becerilerinde artış gösterdikleri söylenebilir.

Deney ve kontrol grubunda bulunan çocukların "Sosyal Uyumsuzluk" alt faktörüne ilişkin olarak son test-ön test fark puanları incelendiğinde; deney grubundaki çocukların son test-ön test fark puanları $(\bar{X}=1,00)$ ile kontrol grubunda bulunan çocukların son test-ön test fark puanları $(\bar{X}=2,47)$ arasında $\mathrm{t}_{(34)}=-2,424$, $\mathrm{p}=, 021<, 05$ 'e göre anlamlı farklılık olduğu görülmektedir. Bu anlamlı farklılaşma, deney grubunun son test-ön test arasındaki süreçte sosyal uyumsuzluk düzeylerinde kontrol grubuna göre negatif yönde bir değişim olmasından kaynaklanmaktadır. Bu bulguya göre; deney grubundaki çocuklara uygulanan Yaşam Becerisi Eğitim Programının çocukların Sosyal Uyumsuzluk davranışı sergileme düzeylerine negatif yönde bir etki ettiği sonucuna ulaşılmaktadır. Uygulanan eğitim programının deney grubunda sergilenen sosyal uyumsuzluk davranışlarının azalmasında etkili olduğu söylenebilir.

Tablo 10'da deney grubunda bulunan çocukların Sosyal Uyum Beceri ölçeğinin alt faktörlerine ilişkin son test puanları ile izleme testi puanları arasında anlamlı farklılığın olup olmadığının incelendiği görülmektedir.

Tablo X

Deney Grubundaki Çocukların Sosyal Uyum Beceri Ölçeğinin Alt Faktörlerine İlişkin Son Test Puanları ile İzleme Testi Puanları Arasındaki Farkllı̆̆̆a Ait Eşleştirilmiş Örneklemler T-Testi Sonuçları

\begin{tabular}{llllllll}
\hline Alt Faktörler & Test & $\mathbf{N}$ & Ortalama & $\mathbf{S}$ & $\mathbf{t}$ & $\mathbf{s d}$ & $\mathbf{p}$ \\
\hline \multirow{2}{*}{ Sosyal Uyum } & Son & 19 & 33,00 & 1,60 & \multirow{2}{*}{1,455} & \multirow{2}{*}{18} & \multirow{2}{*}{163} \\
\multirow{2}{*}{ Sosyal Uyumsuzluk } & İzleme & 19 & 32,89 & 1,59 & & & \multirow{2}{*}{, 841} \\
& Son & 19 & 12,16 & 1,38 & \multirow{2}{*}{, 203} & 18 & 1,27 \\
\hline
\end{tabular}

$\overline{{ }^{*} \mathrm{p}<, 05}$

"Sosyal Uyum" alt faktöründe deney grubunda bulunan çocukların son teste ait sosyal uyum becerisi puanı $(\bar{X}=33,00)$ ile izleme testi sosyal uyum becerisi puanı $(\bar{X}=32,89)$ arasında $\mathrm{t}_{(34)}=1,455, \mathrm{p}=, 163>, 05^{\prime}$ e göre 
anlamlı farklılık olmadığı görülmektedir.

Süreç bitiminde son test uygulaması yapıldığında elde edilen sosyal uyum becerisi puanları ile deney grubunda bulunan çocukların belirli bir zaman dilimi geçtikten sonra sosyal uyum beceri düzeylerini yeniden ölçmek için uygulanan izleme testi puanları arasında anlamlı bir farklılık olmadığı görülmektedir. Deney grubundaki çocukların sosyal uyum becerisi bağlamında edindikleri becerilerde kalıcılığın gerçekleştiği sonucuna ulaşılmaktadır.

Deney grubundaki çocukların "Sosyal Uyumsuzluk" alt faktörüne ait son test puanı $(\bar{X}=12,16)$ ile izleme testi puanı $(\bar{X}=12,21)$ arasında $t_{(34)}=-, 203, p=, 841>, 05$ 'e göre anlamlı farklılık olmadığı görülmektedir. Yaşam Becerileri Eğitim programının uygulanmasının bitiminden belli bir süre geçtikten sonra deney grubuna yeniden uygulanan izleme testinde anlamlı farklılaşmanın gerçekleşmemiş olması; deney grubundaki çocuklarda süreç içerisinde gerileme kaydeden sosyal uyumsuzluk davranışlarındaki bu gelişmenin izleme testine kadar olan süreçte de devam ettiğini ortaya koymaktadır. Bu durum deney grubundaki çocukların sosyal uyumsuzluk davranışlarındaki gerilemenin kalııı bir duruma geçtiğini göstermektedir.

\section{Sonuç ve Tartışma}

Okul öncesi dönemde etkili ve bütüncül bir bakış açısıyla ele alınan yaşam becerileri ve bileşenlerine yönelik eğitim, sadece eğitim alan bireyi değil bireyin donatılmasıyla birlikte yaygın bir etki göstererek yakın çevresini ve dolayısıyla toplumu (De Jong ve diğerleri, 1995) da olumlu yönde etkiler. Toplumsal yaşama uyum sağlayabilmenin getirdiği olumlu hisler (Roodbari, Sahdipoor ve Ghale, 2013) bireydeki içsel motivasyonu harekete geçirerek daha verimli bireyler olmalarını sağlayabilir. Yaşam becerileri eğitim programının uygulanmasından sonra elde edilen son test bulgularına göre; deney grubunda yer alan çocukların son teste ait sosyal uyum beceri düzeyleri ile kontrol grubunda yer alan çocukların son teste ait sosyal uyum beceri düzeyleri incelendiğinde, $\mathrm{t}_{(34)}=12,797, \mathrm{p}=, 000<, 05^{\prime}$ e göre deney grubu lehine anlamlı bir farklılık oluştuğu görülmektedir. Bu durum deney grubundaki çocuklara uygulanan yaşam becerileri eğitim programının etkili olduğunu ortaya koymaktadır. Yaşam becerileri eğitim programı çocukların sosyal uyum becerilerini güçlendirerek toplumda ve ailede daha uyumlu bireyler olmalarının yolunu açabilir. Samarei ve Lalifaz (2005), yaşam becerileri eğitiminin ailedeki stres ve sosyal kabul üzerindeki etkisini inceledikleri araştırmalarında, çocuklara ve anne-babalara uygulanan yaşam becerileri eğitiminin ailedeki stresi azaltarak sosyal kabul üzerinde olumlu ve arttırıcı yönde etki ettiğini saptamışlardır. Bu durum araştırmanın bulgularıyla örtüşmekle birlikte etkili bir yaşam becerileri eğitim programının doğrudan ve dolaylı birçok alana etki ettiğini de açıklamak açısından önemlidir. Çünkü araştırmada kullanılan sosyal uyum beceri ölçeğinin "Sosyal Uyum" alt faktörü olmakla birlikte bir de "Sosyal Uyumsuzluk" alt faktörü bulunmaktadır. Deney ve kontrol grubunun "Sosyal Uyumsuzluk" alt faktörüne ilişkin puanları incelendiğinde deney grubunun son test puanlarında kontrol grubunun son test puanlarına göre negatif yönde bir değişim görülmektedir. Bu durum uygulanan eğitim programının çok yönlü olmasından kaynaklı olarak deney grubundaki çocukların "Sosyal Uyumsuzluk" düzeylerinde gerileme sağladığının anlaşılması açısından anlamlidir.

Adibsereshki, Vernosfaderani ve Movallali (2015)'nin okul öncesi kaynaştırma okullarındaki çocuklar için geliştirdikleri yaşam becerileri eğitim programının çocukların sosyal becerilerine etkisini inceledikleri çalışmalarında, atılganlık, öz-kontrol ve işbirliği gibi becerilerde uyguladıkları eğitimin etkili olduğunu saptamışlardır. Bu durum araştırmadaki “Okul Öncesi Dönem Yaşam Becerileri Ölçeği”"nin alt faktörlerinden olan "Sosyal Yaşam" boyutuna ilişkin elde edilen bulgularla benzerlik taşımaktadır. Deney grubundaki çocukların "Sosyal Yaşam" alt faktörüne ilişkin son test puanlarında kontrol grubundaki çocuklara göre $\mathrm{t}_{(34)}=2,25, \mathrm{p}=, 031<, 05$ 'e göre anlamlı farklılık görülmektedir. Nitekim ölçeğin "Sosyal Yaşam" alt faktöründe atılganlık ve işbirliği gibi becerileri içeren maddeler yer almaktadır.

Yaşam becerileri eğitim programının esas olarak çocuğun genel potansiyelini kendi öz farkındalığı ve benlik saygısı aracılığıyla güçlendirmek gibi bir örtük misyonu da olabilir. "Okul Öncesi Dönem Yaşam Becerileri Ölçeği"nin "Öz Farkındalık" alt faktörü bu nedenle önem taşımaktadır. Benlik saygısı ve öz 
farkındalığı güçlenmiş bireyler yaşamdaki adımlarını daha bilinçli ve kontrollü atarlar. Dolayısıyla etkili bir yaşam becerileri eğitimin ana çekirdeği çocuğun iç dünyasındaki gizil gücü ortaya çıkarmaktır.

Vernosfaderani (2014) okul öncesi kaynaştırma okullarındaki çocukların benlik saygılarını yaşam becerileri eğitimi yoluyla geliştirmeyi amaçladığı çalışmasında, 14 oturum ve 7 haftadan oluşan ve her oturumu 120 dakika olarak planlanan bir yaşam becerileri eğitimi hazırlamıştır. Uygulanan eğitimin sonucunda çocuklardaki benlik saygısı düzeylerinin anlamlı düzeyde artış gösterdiği sonucuna ulaşmıştır. Bu sonuç araştırmanın sonuçlarıyla da benzer nitelikler taşımaktadır. Topcu Bilir (2019)'in, Yaşam Becerileri Programı'nın beş yaş grubu çocukların yaşam becerileri, benlik algıları ve sosyal duygusal uyum düzeylerine etkisini incelediği çalışmasında, yaşam becerileri programına katılan deney grubundaki çocukların yaşam becerileri, benlik algıları ve sosyal duygusal uyum düzeylerinin kontrol grubundaki çocuklara göre anlamlı düzeyde farklılaştığı sonucuna ulaşmıştır. Yaşam becerilerine yönelik olarak çocuklara uygulan eğitim programlarının çocukları bütüncül olarak geliştirdiği ifade edilebilir. Nitekim bu araştırmada da deney grubundaki çocukların Okul Öncesi Dönem Yaşam Becerileri ölçeğinin gerek "sosyal yaşam" alt faktörü gerekse "öz farkındalık" alt faktörüne yönelik bulguları incelendiğinde deney grubundaki çocukların son-test puanlarında kontrol grubundaki çocuklara oranla anlamlı düzeyde farklılaşma olduğu görülmektedir. Bu anlamlı farklılaşmanın deney grubundaki çocuklara uygulan eğitim programından kaynaklandı̆̆ ifade edilebilir.

Araştırma sonuçlarına göre deney grubunda yer alan çocukların eğitimin etkisine bağlı olarak sosyal uyum ve sosyal yaşam düzeylerinde kontrol grubundaki çocuklara oranla anlamlı bir farklılaşma görülmektedir. Behroz-Sarcheshmeh, Karimi, Mahmoudi, Shaghaghi, ve Jalil-Abkenar (2017) zihinsel yetersizliği bulunan lise öğrencilerine yönelik uyguladıkları yaşam becerileri eğitim programının öğrencilerin işbirliği ve öz-kontrol gibi sosyal becerilerine olumlu etki ettiği sonucuna ulaşmışlardır. Behroz-Sarcheshmeh ve diğerleri (2017)'nin, öğrencilerin, yaşam becerileri eğitim programıyla eğitim sürecinin dışında kalan zamanlarda da desteklenmesini vurguladıkları çalışmada elde ettikleri bulgular, yaşam becerilerinin çocukların hayatının her alanında desteklenmesi gereken beceriler olduğu düşüncesini pekiştirebilen bir sonuç olarak gösterilebilir.

Eissa (2018) okul öncesi dönem çocuklarının yıkıcı ve antisosyal davranışlarının iyileştirilmesi amacıyla yaptığı deneysel çalışmada, erken müdahaleye dayalı bir yaşam becerileri eğitim programı uygulamıştır. Programın uygulanmasından ve izleme çalışmasından sonra çocukların öğretmenlerinden aldığı dönütlerin olumlu olduğunu ve okul öncesi dönem çocuklarındaki yıkıcı ve antisosyal davranışlarda iyileşme görüldüğünü ifade etmiştir. Eissa (2018)'in bulgularına paralel olarak, bu araştırmada da uygulanan yaşam becerileri eğitim programının deney grubundaki çocukların yaşam becerilerinin temel bileşenlerinden olan kişiler arası iletişim becerisi, duygularla baş etme becerisi ve stresle baş etme becerilerinde yaşam becerileri ölçeğinden aldıkları son test puanlarına göre olumlu yönde bir farklılaşma olduğu sonucuna ulaşılmıştır. Bu bulgular, yaşam becerileri eğitimine katılan çocukların, Rooth (2000)'un çalışmasında vurgulanan, kapasite oluşturma sürecinin, çocukların içinde yaşadığı toplulukta güçlenmelerini ve girişimde bulunmalarını sağlamaya yardımcı olan bir süreçtir ifadesini güçlendirmektedir; çünkü yaşam becerileri eğitimi kişinin sosyal yaşamdaki kişisel ve kişiler arası yetkinliğini ve güvenini destekleyerek onun sorunlarla başa çıkma kaynaklarını geliştirir (Donald ve diğerleri, 1999).

Gunning, Holloway ve Healy (2019), okul öncesi dönem çocukları ile yaptığı çalışmada, İrlandalı çocukların okula hazır oluş süreçlerinin desteklenmesi ve problem davranışların azaltılması amacıyla çocuklara yaşam becerileri eğitim programı uygulamışlardır. Hanley, Heal, Tiger ve Ingvarsson (2007) tarafından geliştirilen "Okul Öncesi Yaşam Becerileri Programı"nın uygulandığı çalışmada okula hazırlık açısından önem taşıyan on üç okula hazırlık becerisi üzerinde yoğunlaşmışlardır. Araştırmanın sonuçlarına göre; çocukların okula hazırbulunuşluk düzeylerinde artış yaşanırken problem davranışlarında azalma görülmüştür. Bu bulgular çalışmanın başlangıç bölümünde açıklanan yaşam becerilerinin temel bileşenlerinin sistemli bir biçimde verilmesiyle birlikte çocuğun çok yönlü gelişimine, onu hayata hazırlamaya ve onun kendi kendine yetebilen (WHO, 2013) bir birey olmasına etki ettiğini açıklaması açısından önem taşımaktadır. 
Çalışmanın başlangıç bölümünde ifade edilen ve açıklanan yaşam becerilerinin temel bileşenleri ve bu bileşenlerin ilişki ağı aşağıdaki şekildedir (WHO, 1997).

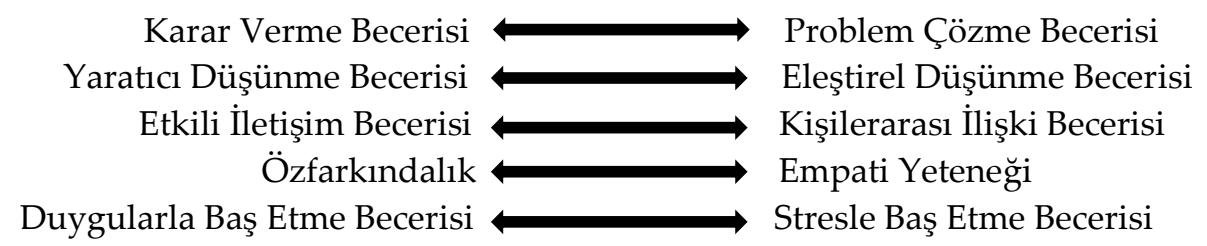

Dünya Sağlık Örgütü (WHO, 2013) yaşam becerilerinin on temel bileşeni olduğunu vurgulamıştır. Bu temel bileşenler kendi içlerinde birbiriyle olan ilişkilerinden dolayı birlikte ele alınabilirler. O nedenle birbiri ile birlikte düşünülebilecek temel bileşenler karşılıklı ok yöntemiyle ilişkisel olarak yukarıda ifade edilmiştir. Araştırmada yaşam becerilerini okul öncesi dönem çocukları açısından tasarlarken bu temel bileşenlerin "Yaşam Becerileri Eğitim Programına" ve "Okul Öncesi Dönem Yaşam Becerileri Ölçeği"ne de entegre edilmesi çabası verilmiştir. “Okul Öncesi Dönem Yaşam Becerileri Ölçeği” ni oluşturan faktörlere bakıldığında "Sosyal Yaşam”, "Sorumluluk", “Özfarkındalık”, “Cinsiyet Farkındalığı", "Karar Verme”, "Hayatta Kalma” ve "Özbakım" olduğu görülmektedir. Bu yedi alt faktör içerisine yaşam becerilerinin temel bileşenleri işlenmiştir. Sosyal Yaşam alt faktörü içerisine; etkili iletişim, kişilerarası ilişkiler, empati, eleştirel düşünme becerisi gibi bileşenler; "Karar Verme" alt faktörü içerisine "problem çözme", "yaratıcı düşünme" gibi bileşenler; "Öz farkındalık" alt faktörü içerisine "duygularla baş etme" ve "stresle baş etme" gibi bileşenler harmanlanmiştır.

Birleşmiş Milletler (UN), Dünya Sağlık Örgütü (WHO), Birleşmiş Milletler Çocuklara Yardım Fonu (UNICEF) ve UNESCO gibi dünyanın global düzeydeki en önemli kurumları dünya üzerindeki çocukların çağın gereklerine uygun yaşam becerileriyle donatılmış bireyler olmaları için çalışmalar yürütmektedirler. Bu kurumların yapılan araştırmalar sonucunda hazırladıkları raporlarda (WHO, 2013; UNESCO, 2000) çocukların gereksinim duydukları yaşam becerilerinin ülkeler arasında değişkenlik gösterdiği tespit edilmiştir. Ortaya çıkan bu ihtiyaç değişkenliklerini salt olarak "Gelişimde bireysel farklılıklar vardır." ilkesi ile açıklamak yeterli değildir. Çünkü dünya üzerinde farklı coğrafyalarda yaşayan çocukların gerek sosyodemografik yapı özellikleri gerek ülkelerin refah seviyeleri gerekse de üzerinde yaşadıkları coğrafyanın koşulları gibi durumların bu değişkenliklerde önemli etmenler olduğu belirtilmektedir.

\section{Sinırlılıklar ve Öneriler}

Araştırmanın sonuçlarından hareketle çalışma grubuna uygulanan "Yaşam Becerileri Eğitim Programı"nın çocukların yaşam becerilerinin gelişimini desteklediği ifade edilebilir. Bununla birlikte çocuklara uygulanan "Yaşam Becerileri Eğitim Programı"nın kapsamı ve içeriğinin Türkiye koşulları dikkate alınarak oluşturulduğu ve bu nedenle Türkiye şartlarında etkili sonuçlar verebileceği dikkate alınmalıdır. Araştırmanın giriş ve tartışma kısmında da vurgulandığı üzere günümüz dünyasında her toplumun ve kültürün kendisi açısından belirleyici olan yaşam becerileri bulunmaktadır. Bu nedenle araştırmada uygulanan "Yaşam Becerileri Eğitim Programı" Türk toplumu ve kültürünün ihtiyaç duyduğu yaşam becerileriyle sınırlı olmakla birlikte bu araştırma özelinde de uygulamanın yapıldığı çocuklar ile sınırlıdır. Araştırmacılar geliştirici ve dönüştürücü bilimsel bakış açısıyla Türk toplumu ve kültürü açısından gerekli olan yaşam becerilerini, tarihsel süreç içerisinde yordayarak eksik olduğu düşünülen becerileri giderme yolunu izleyebilirler. Ayrıca Türkiye'deki okul öncesi eğitim kurumlarında günümüz çocuklarının ihtiyacı olan yaşam becerilerinin desteklenmesi için Okul Öncesi Eğitim Programı'nda yer alan kazanım/göstergelerin revize edilmesi ve "Yaşam Becerileri Gelişim Alanı" şeklinde bir alan eklenerek eğitimciler üzerinde farkındalık oluşturulması önerilmektedir.

\section{Yazar(lar)ın Beyanı}

Araştırmacıların katkı oranı beyanı: Araştırmanın veri toplama sürecinde, eğitim programının hazırlanmasında ve araştırmanın raporlaştırılmasında her iki yazar da işbirliği içerisinde ve eşit düzeyde araştırmanın oluşumuna katkıda bulunmuşlardır. Araştırmacılardan Yakup Yıldırım eğitim programının deney grubuna uygulamasını yapmıştır. 
Yaşam Becerileri Eğitim Programının Anasınıfına...

Çatışma beyanı: Araştırmada, yazarların kendi içinde ve diğer kişi/kurum/kuruşlarla herhangi bir çıkar çatışması söz konusu yoktur.

Destek ve teşekkür: Bu araştırmanın yürütülmesi esnasında Amerika Birleşik Devletlerindeki uygulamaların yerinde incelenebilmesi ve çalışmanın güçlendirilebilmesi adına doktora eğitimi sürecinde Tübitak 2214-A Doktora Sırası Araştırma Burs programından destek alınmıştır.

\section{Kaynaklar}

Adibsereshki, N., Vernosfaderani, M. A. ve Movallali, G. (2015) The effectiveness of life skills training on enhancing the social skills of children with hearing impairments in inclusive schools. Childhood Education, 91(6), 469-476.

Arı, M. (2005). Eğitimde yeni yaklaşımlar. İstanbul: Morpa Kültür Yayınları.

Behroz-Sarcheshmeh, S., Karimi, M., Mahmoudi, F., Shaghaghi, P. ve Jalil-Abkenar, S. S. (2017). Effect of training of life skills on social skills of high school students with intellectual disabilities. Journal of Practice in Clinical Psychology, 5(3), 177-186. doi: 10.18869/acadpub.jpcp.5.3.177

Büyüköztürk, Ş. (2007). Deneysel desenler: Öntest-sontest kontrol grubu desen ve veri analizi (2. bs). Ankara: Pegem Akademi Yayınları

Cinkılıç, H. (2009). Okul öncesi eğitimin ilköğretim 1. Sınıf öğrencilerinin okul olgunluğuna etkisinin incelenmesi (Yüksek lisans tezi). Selçuk Üniversitesi, Sosyal Bilimler Enstitüsü, Konya.

Cinkılıç İnel H., Çağdaş, A. ve Temiz, G. (2012, Mart). Pre-School education's effect on first class elementary school students' school maturity. International Conference on Management, Applied and Social Sciences (ICMASS'2012). Dubai, Birleşik Arap Emirlikleri.

De Jong, T., Ganie, L., Lazarus, S. ve Prinsloo, E. (1995). Proposed general guidelines for a Lifeskills curriculum framework. Gordon, A. (Ed.), Curriculum framework for the general phase of education (s.91108) içinde. Johannesburg: Centre for Education Policy Development.

Donald, D., Lazarus, S. ve Lolwana, (1999). The development of education support services in South Africa the process of transition: Goals and strategies. South African Journal of Education, 15(1), 52-57.

Eissa, M. A. (2018). The effectiveness of a life skills training based on the response to intervention model on improving disruptive behavior of preschool children. International Journal of Psycho-Educational Sciences, $7(2), 60-66$.

Erbil, O., Demirezen, S., Erdoğan, A., Terzi, Ü., Eroğlu, H. ve İbiş, M. (2004). Öğrenci Merkezli eğitim uygulama modeli. İzmir. İktisat Kongresi Eğitimde Uygulamalar Bölümü Tebliği.

Erkan, S. (2011). Farklı sosyoekonomik düzeydeki ilköğretim birinci sınıf öğrencilerinin okula hazırbulunuşluklarının incelenmesi. Hacettepe Üniversitesi Ĕ̆itim Fakültesi Dergisi, 40(40), 186-197.

Erkuş, A. (2013). Davranış bilimleri için bilimsel araştırma süreci (4. bs.). Ankara: Seçkin.

Esaspehlivan, M. (2006). Okul öncesi eğitim kurumuna gitmiş ve gitmemiş 78 ve 68 aylık çocukların okula hazırbulunuşluklarının değerlendirilmesi (Yüksek lisans tezi). Marmara Üniversitesi, Eğitim Bilimleri Enstitüsü, İstanbul.

Francis, M. (2007). Life skills education. 13 Ağustos 2017 tarihinde www.changingminds.org adresinden erişildi.

Gunning, C., Holloway, J. ve Healy, O. (2019) Evaluating the preschool life skills program to teach school readiness skills: An irish pilot study. European Journal of Behavior Analysis, 20(1), 48-68, doi: 10.1080/15021149.2018.1531962

Hanbury, C. (2008). The life skills handbook. Self-published as an e book. 10 Ekim 2018 tarihinde http://www.lifeskillshandbooks.com adresinden erişildi. 
Hanley, G. P., Heal, N. A., Tiger, J. H. ve Ingvarsson, E. T. (2007). Evaluation of a classwide teaching program for developing preschool life skills. Journal of Applied Behavior Analysis, 40(2), 277-300. doi:10.1901/jaba.2007.57-06.

Işık, M. (2007). Anasınıfına devam eden beş-altı yas çocuklarına sosyal uyum ve beceri ölçeğinin uyarlanması ve uygulanması (Yüksek Lisans Tezi). Gazi Üniversitesi, Eğitim Bilimleri Enstitüsü, Ankara.

Kord-Noghabi, R. ve Sharifi, H. P. (2008). Preparation and compilation of a life skills curriculum for students in the high school period. Journal of Educational Innovations, 7(24), 47-56.

Köklü, N., Büyüköztürk, Ş. ve Bökeoğlu, Ç. Ö. (2007). Sosyal bilimler için istatistik. Ankara: Pegem.

Leech, N. L., Morgan, G. A., Gloeckner, G. W. ve Barrett, K. C. (2004). SPSS for introductory statistics: Use and interpretation. Mahwah, New Jersey: Lawrence Erlbaum.

Mağden, D., ve Şahin, S. (2002). Beş-altı yaş grubu çocuklarının akademik becerilerini değerlendirmeye yönelik pilot bir çalışma. Çocuk Gelişimi ve Eğitimi Dergisi, 1(67), 44-60.

Mangrulkar, L., Whitman, C. V. ve Posner, M. (2001). Life skills approach to child and adolescent healthy human development. Washington, D.C.: Pan American Health Organization.

Murthy, C. G. V. (2016). Issues, problems and possibilities of life skills education for school going adolescents. The International Journal of Indian Psychology, 3(3), 56-76.

Parlakyıldız, B. (2008). Portfolyoya dayalı değerlendirmenin üniversite öğrencilerinin akademik başarılarına ve bilişsel yaşam becerilerine etkisi (Doktora Tezi). Gazi Üniversitesi, Eğitim Bilimleri Enstitüsü, Ankara

Poyraz, H. ve Dere, H. (2003). Okul öncesi eğitiminin ilke ve yöntemleri. Ankara: Anı Yayıncılık.

Roodbari, Z., Sahdipoor, E. ve Ghale, S. (2013). The study of the effect of life skill training on social development, emotional and social compatibility among first- grade female high school in Neka City. Indian Journal of Fundamental and Applied Life Sciences, 3(3), 382-390.

Rooth, E. (2000). Introduction to lifeskills: Hands-on approaches to lifeskills education. Cape Town: Via Afrika.

Samarei, A. A. ve Lalifaz, A. (2005). Effectiveness of life skills education on family stress and social acceptance. Quarterly Journal of Fundamentals of Mental Health, 7(25), 47-55.

Senemoğlu, N. (2012). Gelişim öğrenme ve öğretim kuramdan uygulamaya (21. bs.). Ankara: Pegem Akademi Yayınları.

Spence, S. H. (2003). Social skills training with children and young people: Theory, evidence and practice. Child and Adolescent Mental Health, 8(2), 84-96.

Şentürk Aydın, R. (2013). Yaşam becerileri psikoeğitim programının boşanmış aile çocuklarının uyum düzeylerine etkisi (Yayımlanmamış Yüksek Lisans Tezi). Ankara Üniversitesi, Eğitim Bilimleri Enstitüsü, Ankara.

Teke, H. (2010). Ana sınıfı öğretim programının ilköğretim 1. kademe 1. sınıf öğrencilerinin hazırbulunuşluk düzeylerine etkisinin öğretmen görüşlerine göre incelenmesi (Yayımlanmamış yüksek lisans tezi). Selçuk Üniversitesi, Sosyal Bilimler Enstitüsü, Konya.

Topcu Bilir, Z. (2019). Yaşam becerileri programının beş yaş çocuklarının yaşam becerileri, benlik algıları ve sosyal duygusal uyum düzeylerine etkisi (Doktora Tezi). Hacettepe Üniversitesi, Eğitim Bilimleri Enstitüsü, Ankara.

Turaşlı Kuru, N. (2015). Okul öncesi eğitimin tanımı, kapsamı ve önemi. G. Haktanır (Ed.), Okul Öncesi eğitime giriş (s.1-24) içinde. Ankara: Anı Yayıncılık.

Ulusoy, A. (2015). Öğrenme. A. Ulusoy (Ed.), Gelişim ve öğrenme psikolojisi (8. bs.) (s. 139-150) içinde. Ankara: Anı Yayıncilık.

United Nations Educational, Scientific and Cultural Organization. (2000, Nisan). The dakar framework for action, education for all: Meetings our collective commitments. World Education Forum, Dakar- Senegal. 
Vernosfederani, M. A. (2014). The effectiveness of life skills training on enhancing the self-esteem of hearing impaired students in inclusive schools. Open Journal of Medical Psychology, 3, 94-99.

World Health Organization. (1999). Partners in life skills education: Conclusions from a United Nations inter-agency meeting. Geneva, Switzerland: WHO Department of Mental Health.

World Health Organization. (2013). Life skills education in schools. Program on mental health. Division of mental health and prevention of substance abuse. Geneva: World Health Organization.

Yankey, T. ve Biswas, U. N. (2011). Life skills training as an effective intervention strategyto reduce stress among Tibetan refugee adolescents. Journal of Refugee Studies, 25(4), 514-536.

Yavuz, K. E. (2004). Ergenlik döneminde yaşam becerileri eğitimi. Ankara: Ceceli Yayınları.

Yavuzer, H. (2000). Çocuk eğitimi el kitabı (10. bs.). İstanbul: Remzi Kitabevi.

Yıldırım, Y. (2017). Anasımıfına devam eden çocuklara uygulanan yaşam becerisi eğitim programının çocukların yaşam becerilerine ve sosyal uyumlarnna etkisi (Doktora Tezi). Gazi Üniversitesi, Eğitim Bilimleri Enstitüsü, Ankara.

Zembat, R. (2007). Okul öncesi eğitimde nitelik. A. Oktay ve Ö. Polat Unutkan (Ed.), Okul öncesi eğitimde güncel konular (s. 25-44) içinde. İstanbul: Morpa Kültür Yayınları. 


\section{EXTENDED ABSTRACT}

\section{Introduction}

Life skills can be supported too by supporting to child's holistic development with a good education to be given to the child in the pre-school period. Life skills should not be considered separately from development areas. Considering that development continues in consecutive and successive stages in early childhood (Senemoğlu, 2012), gaining one skill affects the acquisition of other skills too. For this reason, while the life skills of pre-school children are being supported (Hanbury, 2008), their holistic development should be supported in coordination at the same time as well.

The teacher should also offer the child an educational program enriched with activities that can support their holistic development in life skills education in which the child can actively participate. During education, the development of the child should be monitored, strengths and weaknesses should be identified, and education should be planned according to different situations.

Preschool education, which is a critical period for children, is a period that should be supported in all developmental areas of the child (Ar1, 2005; Zembat, 2007). The child steps into socialization in the pre-school period and acquires the skills that will form the basis for his future life. The skills and experiences that the child acquires in these years form the basis for his future life. Trying to support the development areas later on, which the child should be supported in these periods, causes delays for the child that cannot be compensated (Senemoğlu, 2012; Turaşlı Kuru, 2015; Yavuzer, 2000).

With the acquisition of life skills, the child will continue to live as a self-sufficient individual who can cope with the difficulties that may arise in his life.

Supporting the life Skills; "Effective Communication Skill (1)", "Self-Awareness Skill (2)", "Empathy Ability (3)”, "Decision-Making Skill (4)”, “Creative Thinking Skill (5)”, "Problem Solving Skill (6) ", " Critical Thinking Skill (7) ", "Interpersonal Relationship Skill (8) ", " Coping with Emotions Skill (9) "and" Coping with Stress Skill (10)"(Hanbury, 2008; Yankey \& Biswas, 2011; World Health Organization, 1997) with other areas of development of the child has an impact which strengthens their future learning in other periods of the child's life; this is possible with the education provided in pre-school period (Mağden \& Şahin, 2002; Poyraz \& Dere, 2003; Ulusoy, 2015).

\section{Method}

A semi-experimental pattern with a pretest-posttest control group, in which the effect of the "Life Skills Education Program" which had been applied to 5-6 years old (60-72 months) children attending pre-school education institution, was tested on life skills, social adaptations, and communication skill in this study.

The study group of the study consisted of children between the ages of 5-6 (60-72 months) who are studying in a foundation / private kindergarten in the city center of Ankara. In this direction, two groups, namely experimental and control groups, have been determined with the purposeful sampling method (homogeneous sampling).

"Preschool Life Skills Scale" developed by Yıldırım (2007) to measure the life Skills and (2017) has been applied to the first group, the experimental group (EG) and "Social Adaptation Skill Scale" developed by Yıldırım (2007) to measure social adaptation skills developed by Yıldırım has been applied to the second group, the control group (CG), to check the equivalence of the groups. After the pre-application, the education program, which consisted of 18 sessions and 36 independent life skill activities, was applied to the experimental group for a total of 12 weeks. Children in the control group continued their regular curriculum during this process. At the end of 12 weeks, the last measurement tools which were applied to the students at the pre-application stage were applied to the students in both groups again.

\section{Results}

According to the results of the research; it is seen that the children in the experimental group who 
participated in the "Preschool Life Skills" education differ significantly in their life skills and social adjustment skill levels depending on the effect of education compared to the children in the control group.

According to this;

While there was no significant difference in the pre-test results obtained from the "Preschool Life Skills Scale" and "Social Adaptation Skill" scale of the children in the experimental and control groups participating in the research, it was concluded that there was a significant difference in the post-test results in favor of the experimental group depending on the effect of the education given. There is a significant difference determined in favor of The experimental group in the scales in general and 7 sub-factors of Preschool Life Skills Scale; "Social Life," "Responsibility," "Self-Awareness," "Gender Awareness," "Decision Making," "Survival" and "Self-Care." While it is concluded that there is a significant difference in favor of the experimental group in the sub-factors of "Social Adaptation" and sub-factors of the social adaptation skill scale in favor of the experimental group in post-test results, there is a negative difference in "Social Incompatibility" factor in favor of the experimental group. It can be stated that this negative variation is due to the decrease in the social incompatibility levels of the children in the experimental group, depending on the effect of the education given compared to the children in the control group.

\section{Conclusion}

The education for life skills and its components, which are dealt with from an effective and holistic perspective in pre-school period, affects not only the individual receiving the education but also the individual and his close environment and the society in a positive way. The happiness of adapting to social life can activate the inner motivation of the individual and enable them to become more productive individuals. According to the post-test findings obtained after the implementation of the life skills education program; when the social adaptation skill levels of the children in the experimental group and the social adaptation skill levels of the children in the control group are examined, it is seen that there is a significant difference in favor of the experimental group. This reveals that the life skills education program applied to children in the experimental group is effective. The life skills education program can strengthen the social adaptability of children and open the way for them to become more compatible individuals in society and in the family. Samarei and Lalifaz (2005) found that life skills education applied to children and parents had a positive and enhancing effect on social acceptance by decreasing the stress in the family in their studies where they examined the effect of life skills education on stress and social acceptance in the family. This situation is critical in terms of explaining that an effective life skills education program affects many areas directly and indirectly, in line with the findings of the research, because the social adaptation skill scale used in the research is a "Social Adoption" sub-factor and there is a "Social Incompatibility" sub-factor. When the scores of the experimental and control groups related to the sub-factor of "Social Incompatibility" are examined, a negative change is observed in the post-test scores of the experimental group compared to the post-test scores of the control group. This situation is meaningful in terms of understanding that children in the experimental group provided a decrease in "Social Incompatibility" levels due to the versatility of the education program implemented. 